
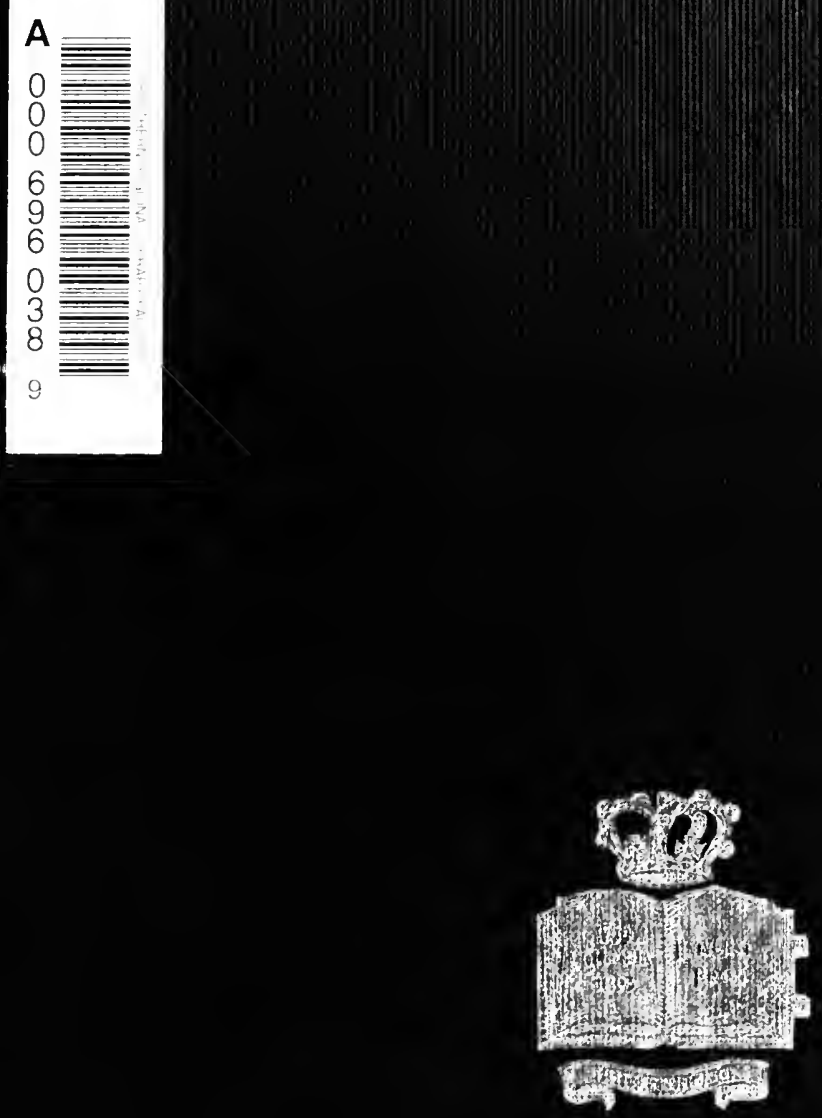


\section{LIBRARY
UNIVERSTY OF
CALIFORNIA
SAN DIEGO \\ LIBRARY
UNIVERSTY OF
CALIFJRNIA
SAN DIEGO \\ LIBRARY
UNIVERSTY OF
CALIFJRNIA
SAN DIEGO


LA JOLLA. LALIFORMIA 



\section{Columbia đanibersity}

STUDIES IN CLASSICAL PHILOLOGY

A STUDY OF ARCHAISM IN EURIPIDES 
COLUMBIA UNIVERSITY PRESS SALES AGENT

NEW York: LEMCKE \& BUECHNER 30-32 West 27th Street

LONDON:

HENRY FROWDE

Amen Corner, E. C. 


\section{A STUDY OF ARCHAISM IN EURIPIDES}

BY

Clarence AUgustus ManNing, Рн.D.

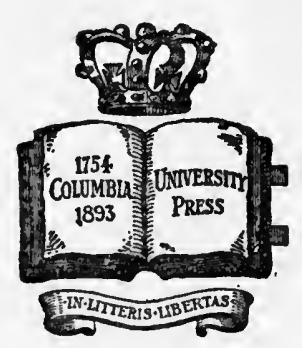

招ew 具otk

COLUMBIA UNIVERSITY PRESS

1916

All rights reserved 
Copyright, 1916

By Columbia University Press

Printed from type, May, 1916 
This monograph has been approved by the Department of Classical Philology of Columbia University as a contribution to knowledge worthy of publication.

Clarence H. Young

Chairman 
Digitized by the Internet Archive in 2007 with funding from Microsoft Corporation 
To

THE PROFESSORS

OF THE

DEPARTMENT OF CLASSICAL PHILOLOGY

COLUMBIA UNIVERSITY 
(20)

(1)




\section{CONTENTS}

CHAPTER PAGE

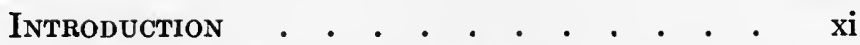

I. The Structure of the Drama . . . . . 1

II. The Prologues and Epilogues of Euripides 27

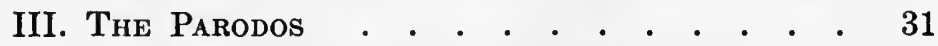

1. The Structure of the Parodos . . . 31

2. The Cause of the Entrance of the

Chorus . . . . . . . . . . . 41

IV. The Iambic Speeches of the Chorus • • . 44

V. The Anapaest . . . . . . . . . . . 51

VI. The Trochaic Tetrameter . • . • • . . 56

VII. DESCRIPTION • • • • • • • • • • • $~ 64$

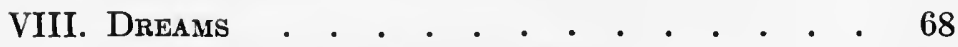

IX. The Religion of Euripides. . . . . . . 73

1. Dionysus . . . . . . . . . . . 74

2. Apollo . . . . . . . . . . . . 83

3. Athena • • • • • . • • • • • 92

BibliogRAPHY. • • . . . • . . . . . . 97 



\section{INTRODUCTION}

In discussing the archaism of Euripides, I may seem to be selecting for emphasis a peculiar aspect of a poet who appears on the whole to represent an advanced point of view. Yet, as is often the case, the radical may propose ideas which have already been discarded by his contemporaries, and the sudden revelation of these may cause them to seem far-sighted prophecies of the future. So with Euripides. Although a sceptic and a critic of the Greek state as he knew it, and the victim of the conservative Aristophanes, yet it was he, and not Sophocles, who was often the conserver and the restorer of the old.

Stalwart champion of the past as Euripides was, in many cases he was unable or unwilling to restore tragedy to its pristine shape, and to remove it further from the works of Sophocles and the lesser poets who so often defeated him. Euripides' plays always reveal their true position in the history of tragedy. The poet shows the influence of Sophocles; he yields to the prejudices of his age. So we need not be surprised if in the course of our examination of his archaisms, we find gaps, inconsistencies, and at times a lack of archaism in passages when we might reasonably expect to see clear examples of it.

I shall here consider some of the ways in which Euripides, the man of curious and ironic history, as Professor Murray terms him, set himself to restore and revivify old forms of tragedy and older usages, and in which he carried on the tradition of Aeschylus, the poet with whom Aristophanes unfavorably compared him in the Frogs. Strange as it may seem to consider the sceptic and recluse, the innovator and reformer, as the successor of the warrior of Marathon, we shall find it true that in many ways Euripides undertook successfully to revive and adapt the methods of Aeschylus, and that we can understand better many of the peculiarities of his dramatic technique, if we consider them from this point of view. 



\title{
A STUDY OF ARCHAISM IN EURIPIDES
}

\author{
CHAPTER I \\ THE STRUCTURE OF THE DRAMA
}

ONE of the most interesting aspects of Euripides' dramatic character is revealed by a study of his way of handling his subjects. The lack of unity in many of his plays is well known, and even in those of more unified type scenes often seem to be inserted in defiance of the rules of dramatic art.

Admirers of Euripides have attempted in many ways to excuse or deny these apparent faults. Prof. Verrall, in Euripides the Rationalist and in Four Plays of Euripides, tries to escape them by supposing the dramas to have one meaning to the general public and another to the educated, sceptical classes. It is remarkable that Aristophanes did not betray the secret, if this were so. Euripides' critics have regarded the lack of unity as an evidence of careless workmanship and have used it to make unfavorable comparisons between him and Sophocles. As Aristophanes does not mention this defect, it may be well to consider whether it exists. Where it does, I think that it is to be explained as due to a tendency to follow the methods of Aeschylus.

Aristotle, in the Poetics, discusses tragedy and epic poetry as if they were closely related forms of art, but he adds that tragedy contains elements which are not found in epic poetry. ${ }^{1}$ He states that the action of a play, unlike that of an epic,

P. 1449 b $18 \mathrm{ff}$. 
should be contained within one revolution of the sun: kai

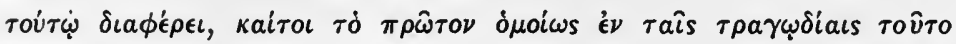

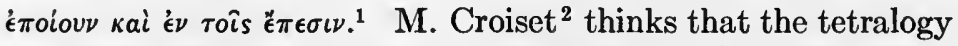
was formed by the division of the chorus into sections which appeared separately at different stages in the course of the dithyramb. Such an origin of the tetralogy is very probable, whatever theory we adopt as to the source of tragedy.

Among the extant dramas of Aeschylus, there is preserved one trilogy, the Oresteia. The satyric drama connected with it has perished, but as it need not have been closely connected by subject, it is relatively unimportant for our present purpose. At times, Aeschylus appears to have used tetralogies in which all the plays were independent. The Persae is probably an example of such a play.

In the Oresteia, there is but one theme - the vengeance of Orestes on his mother for her murder of Agamemnon and his acquittal in a trial at Athens. Similarly the individual plays possess unity. The Agamemnon shows the murder of Agamemnon; the Choephori, the vengeance of Orestes; the Eumenides, the trial and justification of the matricide. Let us now notice a few points in the composition of the three plays.

In the Agamemnon, the description of the beacon-fire and the early choral odes ${ }^{3}$ give the atmosphere. The infidelity of the queen overshadows the joy because of the capture of Troy. The old watchman says:

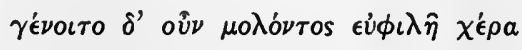

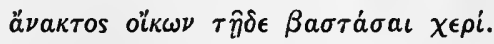

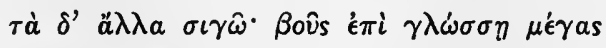

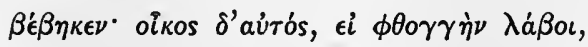

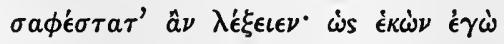

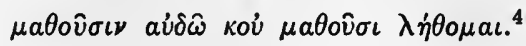

1 P. 1449 b $14 \mathrm{f}$.

${ }^{2}$ De la tétralogie dans l'histoire de la tragédie grecque, Revue des études grecques, Vol. I, p. $373 \mathrm{ff}$.

3 1-487.

4 34-39. 
This watchman was apparently traditional in the story of the house of Atreus. In Odyssey IV, $524 \mathrm{ff}$., a servant of Aegisthus watches a year for the king's return. Prof. Verrall ${ }^{1}$ supposes that the old man is loyal to Agamemnon but that Aegisthus sends the beacon-fire as a signal to the queen. The neglect of time involved in the usual interpretation does not seem so difficult as Prof. Verrall thought, since the Persae and Trachiniae offer as striking cases. ${ }^{2}$ The storm ${ }^{3}$ also has an Homeric source. In Odyssey III, $286 \mathrm{ff}$., Nestor tells how a storm drove Menelaus to Egypt and in this way gave Aegisthus an opportunity to kill Agamemnon alone. It is important to remember that in the play it is the chorus and not Clytaemestra who inquires for Menelaus. In 40-257, the chorus describes the main events preceding the action of the play, especially the sacrifice of Iphigenia, the ostensible cause of Clytaemestra's hatred of her husband. The same recital is in a way continued in $355-487$, an ode in which the chorus pictures the fallen city and the sorrows of victor and vanquished. In 1-781, then, the condition of Argos and Agamemnon is portrayed, while the rumble of the coming storm sounds ever nearer. With matchless unity, every thing conspires to place the king helpless in the hands of his wife, his bitter foe. Since the scenes following the murder show the resolute character of the queen, the unity of the play is unbroken.

In the Choephori, the long threnos and the invocation of Agamemnon ${ }^{4}$ are dramatic in the same sense as the opening scene of the Supplices. The divine powers are gained as helpers. ${ }^{5}$ When the powerful spirit of the murdered king has been gained as a friend, the most important part of the struggle is over. As the recognition of Orestes and Electra is only an episode in

1 Agamemnon, p. xxxix.

2 Cf. Prof. Dyer, The Plot of the Agamemnon, Harvard Studies, Vol. VII, p. $95 \mathrm{ff}$.

489-680.

4 306-513.

- Sheppard, The First Scene of the Suppliants of Aeschylus, Classical Quarterly, Vol. V, p. $220 \mathrm{ff}$. 
the vengeance, it is accomplished by 245 , whereas in the Electra of Sophocles it extends to 1231, and in the Electra of Euripides to 584. The motif of the vengeance so dominates the play that the unity of it is strongly marked.

In the Eumenides, the opening scene ${ }^{1}$ is laid at Delphi. Since in the Choephori Orestes acts by order of Apollo, ${ }^{2}$ it is fitting that in his misery he should return to Delphi to the temple of the god. By this scene, too, the coming of Apollo to Athens for the trial is prepared. An effective scene - the one mortal surrounded by the dread Erinyes and aided only by Phoebus it serves as a bond of union with the Choephori. Finally the importance of Orestes in the play is so skilfully treated and diminished that we do not miss his absence at the end.

The scene at Delphi is only one of the connecting links of the trilogy. Thus in $A g .1279-1285$, Cassandra prophesies the coming of the avenger. In 1646-1648 and 1667, the chorus foretells to Aegisthus the return of Orestes. At the opening of the Choephori, the predictions have been fulfilled and the avenger is at his father's tomb. The threnos recalls the murder of Agamemnon. As the queen enticed her husband into the palace, so Orestes drives her within. ${ }^{3}$ The Furies, promised by Clytaemestra in 924, appear at 1048 and drive Orestes away. The Eumenides shows the flight of the matricide. The appearance of the ghost of Clytaemestra ${ }^{4}$ reminds us of her fate. The trial of Orestes reviews the whole story, and then the play gradually turns to the relations of the old and new divinities.

The Oresteia is really a drama in three acts extending over many years. Each of the component parts possesses unity and the three are connected by many interwoven strands. The trilogy is not only dramatic but also epic and lyric in structure. Unfortunately the loss of the Oresteia of Stesichorus and other such lyric epics prevents us from analyzing the relation
1 1-234.
${ }^{2}$ Cf. Ch. 269-273, 900-902.
3 892-934.
4 94-139. 
of Aeschylus to his sources. The foregoing remarks may serve to indicate the method in which Aeschylus treated the trilogyform.

The Supplices, the earliest of the extant plays, was probably the first play of a trilogy. The account of the voyage of the daughters of Danaus from Egypt ${ }^{1}$ and the emphasis laid on their relationship to Argos through Io would suggest this. Prof. Tucker ${ }^{2}$ remarks that if this were the second play of a trilogy picturing the whole story of the maidens, the third play would contain a disproportionate amount of material. In the lost dramas (perhaps the Aegyptii and the Danaides), were told probably the murder of the sons of Aegyptus on their wedding night and the trial of Hypermnestra for failure to slay her husband and her acquittal through the intercession of Aphrodite. In the Supplices, the lyric elements overshadow in extent and importance those which are purely dramatic. The play might be called The Reception of the Suppliants, since the remaining action serves only to indicate the intention of the Argives to respect their promise. Because of the loss of the other plays, we cannot discuss the structure of the trilogy. Still in 10181073, the division in the chorus over the reverence due to Aphrodite would prepare for the second play. The appearance of Aphrodite in the Danaides probably was similar to that of Apollo in the Eumenides.

From the Hypothesis of the Septem contra Thebas we learn that it was the third play of the trilogy, Laius, Oedipus, Septem. As the trial scene in the Eumenides reviewed in a way the subject of the trilogy, so here the choral ode 720-791 summarizes the fate of the Labdacidae, the theme of this group of plays. As Mr. Sheppard ${ }^{3}$ notes, the drama falls into three divisions, in each of which the situation is created by a messenger. In 1-368, Eteocles calms the women; in 369-791, he chooses the champions and leaves to meet Polynices; finally in 792-1084,
1 1-18.
2 Supplices; p. xxiv.
${ }^{3}$ Greek Tragedy, p. 57. 
the death of the brothers is bewailed and Antigone with part of the chorus insists on burying Polynices. The conclusion is often attacked because Antigone's defiance of the edict seems an unsatisfactory close. Still the division of the chorus was undoubtedly very effective. Similar is the ending of Euripides' Cyclops where the blinded giant says:

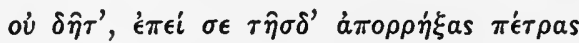

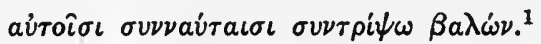

The epic tradition, if fully known, might explain the end of the Septem as well as it does that of the Cyclops. In spite of the divisions in the play, there is a real unity, since the two themes, the saving of Thebes and the fate of the brothers, are closely connected and even fused together.

According to the probable view of Wecklein-Allen, ${ }^{2}$ the Prometheus Vinctus was the first play of the trilogy Prometheus

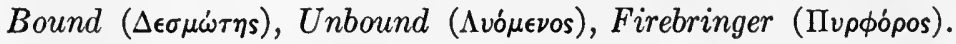
The same editors think that the third play showed the founda-

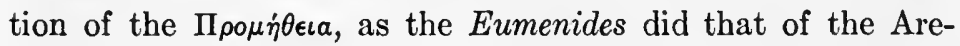
opagus. The Prometheus Vinctus has unity, especially when we consider it as part of the trilogy. The episode of Io prepares for the second play, for it is her descendant.Heracles who is to free Prometheus (771-774). Frag. $199^{3}$ shows something of Heracles' importance in the Solutus. The oracle concerning Zeus' marriage would be prominent in the other plays. It seems certain then that this trilogy also possessed unity of theme and unity of action in individual plays.

Among the extant plays of Aeschylus, the Persae is the only one which seems not to be part of a connected trilogy and it is the only extant non-mythological Greek tragedy. The Hypothesis states that Aeschylus competed with the Phineus, Persae, Glaucus Potnieus, and Prometheus. We do
$1704-705$.
2 Prometheus, p. $19 \mathrm{ff}$.
3 Nauck 2 . 
not need to follow Wilamowitz ${ }^{1}$ in assuming that this information is wrong, and that the Persae was first produced in Sicily and is a trilogy in structure. In spite of the lyric character of the play and the small amount of action, yet because of its glorification of Athens it was undoubtedly a very effective play in that city. The evocation of Darius and the advice which he gives ${ }^{2}$ does not destroy the unity of the plot, since it is introduced to contrast the might of Darius with the humiliation of Xerxes as seen in 909-1076. The procession in the exodos may be compared with those in the Septem and the Eumenides and contrasted with that in the Supplices, where the opposing songs of the semichoruses prepare for the next play.

Aeschylus, then, in using the trilogy, apparently constructed a kind of epic drama or, as Welcker ${ }^{3}$ described it, an epic in which the important moments were acted. There was often, perhaps usually, unity in the trilogy and also in the individual plays. Some seem episodic, but we should probably not have this impression, if we could see the manner in which the part was related to the whole.

The plays of Sophocles, since he treated the individual drama and not the trilogy as the real unit, are of course very different. For the same reason, his method of obtaining unity is not the same as that of Aeschylus.

We commence with perhaps the earliest extant tragedy of Sophocles, the Antigone. At 988, with the entrance of Tiresias, the way is opened for Creon to suffer for his treatment of Antigone. We cannot compare the punishment of Creon with the vengeance on Clytaemestra in the Choephori, since no avengers appear and the outcome is determined by the previous deeds of the characters. Antigone is punished, because she disobeys the edict of Creon which is mentioned in 1-99 and

1 Die Perser des Aischylos, Hermes, Vol. XXXII, p. 382 ff.

3 623-908.

'Aeschylische Trilogie Prometheus, p. $486 . \quad$ 'Jebb, Ajax, p. liii f. 
reaffirmed by the ruler in 192-206, and the impious character of the same edict causes divine punishment to strike Creon through the deaths of his son, Haemon, betrothed to Antigone, and of his wife, Eurydice. In extent the subject is of about the same magnitude as that of a play of Aeschylus, but the treatment is very different. In structure it is nearer to our conception of a drama than is any work of Aeschylus, but it is not therefore more powerful. Perhaps the greatest change made by Sophocles is in the delineation of character. Antigone stands forth very prominently, and her greatness is made more evident by the contrast with the timid Ismene. Creon, too, is developed as a powerful antagonist for Antigone. In this drama more than in any other of Sophocles now extant, the actors in a way represent certain ideas, a tendency almost wholly lacking in the later plays.

The Ajax is of nearly the same date. The second play of the

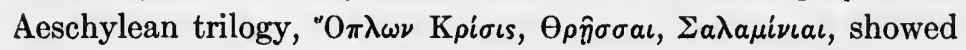
(or rather told of) the suicide of Ajax, and the $\Sigma a \lambda a \mu i v i a \iota$ probably concluded with the establishment of the Aiávreıa. ${ }^{1}$ As the burial of Ajax was an important part of the story, Sophocles was bound to use it, ${ }^{2}$ but he prepares for the dispute by 829-830, where Ajax prays that Teucer may prevent the dishonoring of his body. The importance of burial to a Greek explains the death of the protagonist in the middle of the play, especially when the play shows the making of a hero. The appearance of Odysseus at the beginning and the end also serves to produce unity. We cannot arbitrarily divide the play without doing violence to the author's intentions. Still the character of Ajax is so excellently drawn that to us, if not to the ancients, his death makes a strong point of division in the action of the tragedy.

The Trachiniae again apparently lacks unity, but only apparently. The real theme is the death of Heracles, whose

1 Jebb, Ajax, p. xix ff. $\quad{ }^{2}$ Sheppard, Greek Tragedy, p. $102 \mathrm{ff}$. 
character dominates the plot of the play even long before he appears. Deianira, however, is so charmingly drawn that she seems to be the important figure, and we are led by our sympathies (perhaps more than the Greeks were) to feel that her death destroys the unity instead of being only an incident in the main story.

In the Electra, Sophocles again shifts the interest in the course of the action. He has followed the tradition of Aeschylus, save that Clytaemestra is slain first and that there are no Furies to torment Orestes. The recognition of brother and sister is not completed until 1231. Electra herself is more important and much more strongly emphasized than in the Choephori. To obtain this result while still keeping Orestes as the real avenger, Sophocles has been led to obscure the formal unity, a loss well counterbalanced by the gain in the character of Electra.

If, in the Electra, the emphasis is not laid upon the traditional hero until the play is far advanced, in the Philoctetes it is laid upon a subordinate character practically throughout. It is Neoptolemus, apparently first introduced by Sophocles, ${ }^{1}$ in whom we are chiefly interested, and the traditional solution is gained by the use of the deus ex machina. Probably in the Philoctetes of Aeschylus, Philoctetes himself was the character emphasized.

In the Oedipus Rex, there is no shift of sympathy. Oedipus holds the centre of the stage from the time when he enters as the kind ruler until his final exit, a broken, blinded man. With matchless unity, the action moves on majestically and irresistibly.

We may here briefly mention the Ichneutae, a satyric drama of which a large part has recently been discovered. The theme is the theft of Apollo's cattle and the invention of the lyre by the infant Hermes. The conclusion is not preserved, but I 1 Jebb. Philoctetes, p. xxii. 
think it almost certain that Hermes appeared at the end and at once overshadowed Apollo, who is prominent in the part preserved. The play is apparently formed much as Sophocles' tragedies are.

This brief survey will show us some of the cardinal principles of Sophocles' art. His dramas contain one action and accordingly possess unity, as do the plays of Aeschylus. Yet this is obscured at times by the elaboration of subordinate characters to such an extent that the dramas seem to fall into distinct sections and the impression of unity is materially weakened. Sophocles is primarily a delineator of character. His art produces the Oedipus Rex, where the interest never shifts, but the weaknesses of it are seen in the Trachiniae, where there is a decided shift in emphasis. The reappearance in many plays, towards the end, of a character who had appeared in the beginning ${ }^{1}$ tends to emphasize the unity and at the same time to dissipate any resemblance in movement to that of an epic. As a result, Sophocles' dramas seem of a more modern form than those of Aeschylus.

The Oedipus Coloneus represents a very different type. It falls into three divisions: (1) 1-323, 549-719, the reception of Oedipus at Colonus; (2) 324-548, 720-1455, the attempts to remove him from the protection of Athens; (3) 1456-1779, the passing of Oedipus. The portion 720-1455 again is in two parts: 720-1149, the attempt of Creon in behalf of Eteocles by force; and 1150-1455, the attempt of Polynices by persuasion. Prof. Murray ${ }^{2}$ breaks the symmetry of the piece by not classing as parallel the two attempts. It will be remembered that Aeschylus made the reception of suppliants the theme of the first play of a trilogy. The third division ${ }^{3}$ is rather similar to the Eumenides, since it represents the final settlement of

1 Cf. Platt, The Burial of Ajax, Classical Review, Vol. XXV, p. 102.

2 Ritual Forms in Greek Tragedy, Excursus in Miss Harrison's Themis, p. 358 .

3 1456-1779. 
the action under divine influence. The drama is in a sense a kind of trilogy, since it possesses unity but has three distinct parts with separate actions. The insertion of the arrival of Ismene before that of Theseus ${ }^{1}$ causes interlocked order of the first and second sections and in this way the obscuring of the formal divisions increases the general effect of unity. The bipartite division of the second part, and the position of 1456 which is within the strophe 1447-1456 and connects the second and the third divisions, tend also to increase the impression of unity. We may say briefly that the structure seems epic, as there is a succession of important points in the piece instead of one climax with all details subordinated.

If ancient tradition is correct, as is likely, in assigning this play to the old age of Sophocles, the poet followed a style of tragedy which Euripides had used long before. To the works of the third of the poets we now come.

We will first analyze the Hippolytus, a play produced in 428 B.c. This is commonly considered one of Euripides' masterpieces, and it shows very well his methods of composition. The following scheme will show the structure.

1- 57 Aphrodite announces that she will punish Hippolytus for his neglect of her.

58- 87 Hippolytus praises and crowns Artemis.

88- 113 Despite the advice of a servant, he will not notice Aphrodite.

114- 120 The servant prays to Aphrodite.

121- 169 The chorus of women speculates as to the cause of Phaedra's illness.

170- 372 Phaedra betrays her passion for Hippolytus.

373- 524 The nurse advises Phaedra to gratify it.

525- 564 The chorus praises Eros.

565- 668 Hippolytus refuses the nurse's proposals.

669- 731 Phaedra reproaches the nurse.

1 324-719. 
$732-775$ The chorus prays for peace and quiet.

776- 789 The nurse tells of Phaedra's suicide.

790- 810 Theseus learns of it.

811- 855 Theseus and the chorus lament for Phaedra.

856- 898 Theseus finds the letter incriminating Hippolytus and curses him.

899-1101 He accuses Hippolytus and exiles him. Because of his oath, Hippolytus is silent.

1102-1150 The chorus laments for Hippolytus.

1151-1267 A messenger reports the mishap to Hippolytus.

1268-1281 The chorus sings the praise of Aphrodite.

1282-1466 Artemis reveals the truth. Hippolytus is carried in, pardons his father, and dies.

In this play, the portion 1-120 is clearly marked off and shows the offence of Hippolytus. Unless we accept Prof. Murray's ascription of 1102-1110 and 1120-1130 to the chorus of huntsmen, the separate chorus of this first section does not reappear. There is another break after 855. In 121-855, the subject is the fate of Phaedra. In her last words she hints that she will do mischief. Cf. 728-731:

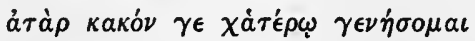

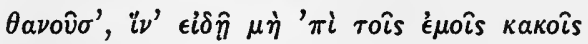

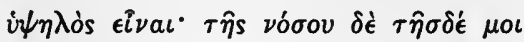

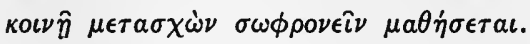

The final section sets forth the fate of Hippolytus and contains the appearance of Artemis, which balances that of Aphrodite in the prologue.

These three sections of the Hippolytus are almost as independent as the plays of an Aeschylean trilogy, although the choral portions are shorter and of less importance than in the plays of Aeschylus. On the other hand, the feud between Aphrodite and Artemis furnishes a unifying influence, and the appearance of the goddesses, one in the prologue, the other in 
the exodos, increases and emphasizes it. Structurally the play is nearer in form to the Oedipus Coloneus than to either the Oedipus Rex or the Antigone. I will not say that Euripides conceived it as a trilogy, but he at least chose an epic type of drama as a model.

The Heraclidae, a play of about the same date, has a similar structure. In 1-380, Iolaos and the children of Heracles are received by Demophon and protected against Eurystheus. The action, a reception of suppliants and the failure of a herald's attempt to remove them, is substantially that of the Supplices of Aeschylus. Still the play of Euripides shows more honor to Athens than that of Aeschylus to Argos, since in the Heraclidae the suppliants have not been formally received by Demophon and so the king is bound only by the general law of kindness to suppliants. Iolaos claims help in 207-212 because of kinship, as do the daughters of Danaus in Supplices $274 \mathrm{ff}$. Krausse ${ }^{1}$ shows many other similarities between this part of the Heraclidae and the Supplices. In 381-629 Macaria sacrifices herself to Demeter and Kore in response to an oracle. In 630-927 the battle is described and in 928-1055, the slaying of Eurystheus by Alcmene. We might obtain a tripartite division by making parallel 381-629 (the sacrifice of Macaria) and 630-747 (the coming of Hyllus and the arming of Iolaos). These could then be compared with the evocation of Agamemnon in the Choephori and the aid given to Orestes by his sister. Thus we could consider 381-927 the second division, and 9281055 (the settlement under divine or heroic influence) can be compared to the Eumenides. We must, however, not press such analysis too far. Euripides probably intended to treat the material in an epic manner rather than in one marked by a severe dramatic unity. The result is similar to an Aeschylean trilogy. Mr. Sheppard neglects this when he says: ${ }^{2}$

${ }^{1}$ De Euripide Aeschyli instauratore, p. 67 f. $\quad{ }^{2}$ Greek Tragedy, p. 141. 
"In each [the Heraclidae and the Supplices of Euripides] the simple theme (a coming of weak suppliants to Athens, a fight for their cause, victory, and the promise of benefits that piety has earned) proves inadequate in these days when the part of the chorus is comparatively small. In each the play is lengthened and the interest complicated by an episode. The excuse is the freedom of the old-fashioned type of drama."

Our ignorance as to the form of Euripides' source prevents an emphatic statement, but we seem to have a kind of trilogy The Reception of Suppliants, The Defeat of the Invaders, The Gaining of Eurystheus as a Hero-ally of Athens.

The Supplices, dealing with the expedition of Theseus to recover the bodies of those who had fallen on the expedition of Adrastus, opens in the usual manner of suppliant-plays. The argument between Theseus and Adrastus is unusual, but such a dispute is indicated in Aesch. Supp. $340 \mathrm{ff}$. where Pelasgus hesitates to receive the maidens. If we followed analogy, we should consider 1-597 as the first section. Krausse ${ }^{1}$ compares the language of these lines to that of the Supplices of Aeschylus. It is harder to analyze 598-1234. If we should consider the second part (the rescue of the bodies) as ending at 1113 , the third division would contain merely the appearance of Athena and the establishment of friendship between Athens and Argos. This, however, would be sufficient for our purpose. In any event, the Evadne-Iphis scene ${ }^{2}$ seems disconnected. In fact the passage 598-1234 is rather similar to the ending of many plays of Euripides. ${ }^{3}$ Perhaps the play is based on a shorter mythos. The Supplices, an '́ $\gamma \kappa \dot{\omega} \mu\llcorner o \nu$ 'A $\theta \eta-$ vai $\omega \nu$ (as the Hypothesis calls it), is structurally successful, since the divisions are not so clearly marked as in either the Heraclidae or the Hippolytus, although the play contains one loosely connected scene.

1 Op. cit., p. 75.

$2980-1113$.

3 Cf. Murray, Ritual Forms, in Themis, p. 354. 
The Andromache is much less unified. 1-308 form a parallel to the opening division of suppliant-plays, but we should probably count 1-801 as the first section, since Menelaus takes Hermione's place in the quarrel with Andromache, and Peleus saves the unhappy woman, much as Pelasgus does the daughters of Danaus in Aesch. Supp. $911 \mathrm{ff}$. Such a change of characters is seen in the Ajax where Agamemnon supports his brother against Teucer. The second division is 802-1046, the departure of Hermione, and the third is 1047-1288, the fate of Neoptolemus. Prof. Verrall's explanation that Neoptolemus had been killed before Orestes left Delphi and that Menelaus, in order that his daughter might leave her husband willingly and marry Orestes, instigated the quarrel with Andromache, ${ }^{1}$ provides unity but is unnecessary. The structure is very lax and the main bond of union is sequence in time. The play seems like a slice from an epic rather than a well constructed drama.

The Hercules Furens is of much the same type. The subject is in two distinct parts, although we may find a tripartite division. In 1-814, the suppliant-motif occurs again. Heracles arrives in time to save his family from death at the hands of Lycus. At 815, Iris and Lyssa appear and Heracles becomes insane and kills his family. The entrance of Theseus at 1153 is to comfort Heracles. Perhaps we should take as the second section 815-1087 and regard it as parallel to the Choephori, which also ends with the protagonist insane. The appearance of the goddesses at the opening of this section is much like that. of Apollo and $\theta$ ávaros in the Alcestis and of Poseidon and Athena in the Troades. Finally, 1088-1428 (the healing and comforting of Heracles) can be compared to the Eumenides, except that a hero, not a god, enters. The only unity in thought is furnished by the idea of the injustice of the gods. Structurally the play is nearer to the Andromache than to the Hippolytus.

The Hecuba has a similar structure. In the first section (1-97),

1 Four Plays of Euripides, p. $28 \mathrm{ff}$. 
the ghost of Polydorus predicts the course of events and Hecuba is terrified by the dream which her dead son sends. This passage may be compared to Hipp. 1-120, in which the offence of Hippolytus is seen and his fate is foretold. The second part (98-656) shows the fate of Polyxena, and the third (657-1295), the punishment of Polymestor for the murder of Polydorus. The character of Hecuba and the prophecy of Polydorus are the main bonds of union. The play can almost be regarded as the presentation of two loosely connected stories. The effect is gained through the delineation of the cruelty of war and the savage nature of the leaders - even of the sons of Theseus ${ }^{1}$ - and not through the dramatic structure.

It may now be convenient to consider the earlier plays of Euripides. If we were determined to find divisions in the $\mathrm{Al}$ cestis, a play which was probably substituted for a satyric drama, we could do so as follows: (1) 1-76, Apollo and Thanatos; (2) 77-475, 568-746, the death and burial of Alcestis; (3) 476-567, 747-1163, the rescue of Alcestis by Heracles. This, however, is artificial. The arrival of Heracles ${ }^{2}$ and the funeral of Alcestis ${ }^{3}$ are treated in interlocked order. Then too the death of Alcestis is not an independent action in the same sense in which this is true of the parts of the Hippolytus. Even if we adopted such a division, the quarrel of Admetus and Pheres ${ }^{4}$ is still loosely connected. I would suggest that Euripides preserved one action but modelled his work after the older type of drama. Structurally this play is very successful as regards unity.

Only one scene in the Medea breaks the dramatic action. Aegeus offers Medea a refuge at Athens, ${ }^{5}$ apparently because in the tradition she did flee to his court. Dramatically therefore it is a fault. Another slight weakness is seen in $1317 \mathrm{ff}$., where Medea receives her dragon-car only in time to save her chil-
1 123-129.
3 568-746.
$5663-763$.
$2476-567$.
${ }^{4} 611-740$. 
dren's bodies. This might arouse ironical reflections on the care of the gods for mortals, but it is a weakness, unless we assume that it was part of the traditional account. If so, it has been treated admirably. This play is almost the least episodic of any of Euripides' extant dramas or, perhaps we might say, the least epic.

The later plays of Euripides are in some ways nearer to these dramas than to those of the epoch of the Hippolytus. The Ion is a thinly veiled attack on Apollo. The scenes are somewhat loosely connected, but the tripartite division (1-509, the bewilderment of Ion; 510-1243, the adoption of Ion by Xuthus and the futile attempt of Creusa to poison the young man; 1244-1622, the recognition of Ion as Creusa's child) is artificial. The characters are few and in fact Ion and Creusa dominate the piece. Then the failure of the attempted murder reveals the secret of Ion's birth and thwarts the plans of Apollo. ${ }^{1}$ There is a romantic touch which is not found previously in the work of Euripides, and in Ion's monody ${ }^{2}$ there is a charming idyllic touch. This play opens a new series of dramas with free but masterly technique and a light touch that might lead to a development into mere melodrama.

The Troades, however, is a remarkable drama. The gloom of the piece is unbroken. In $A g .429 \mathrm{ff}$., Aeschylus paints the horror and the sin of war and exclaims:

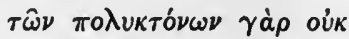

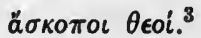

Euripides feels the horror and barbarity of war more than the sin and says:

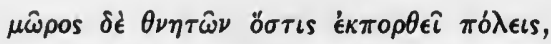

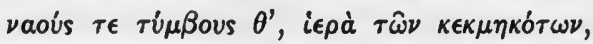

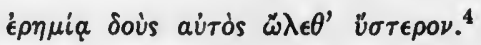

1 Cf. $1563 \mathrm{ff}$.

${ }^{3} 461-462$.

$282-183$.

- $95-97$. 
This is the keynote. The folly and outrages of the Greeks justify the words of Andromache ${ }^{1}$ that the dead are happier than the living. The plot of Athena and Poseidon to destroy the Greek fleet lends an added horror to the whole. The character of Hecuba placed in relation to the other characters furnishes the only excuse for unity. The play is merely a series of scenes showing the sack of Troy, but these are most skilfully constructed. Euripides shows how untrustworthy is the loyalty of the conquered when he represents Hecuba saying to Andromache:

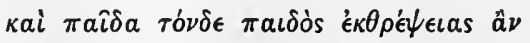

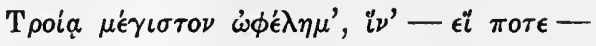

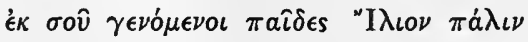

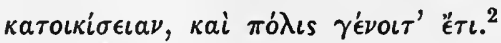

This speech explains why the Greeks decided to kill Astyanax. Although the play is so different from the Ion, the search for effectiveness in individual scenes suggests that it is of much the same date. The position of the scene with Helen in the middle of the description of the fate of Astyanax, seems to be an instance of a device worked out later in the Phoenissae.

In structure, the Electra is quite near the Ion. We do not. find here the romantic note of that play, but there is an appreciation of the excellence of the humble in the depiction of Electra's husband. The details of the play are very different from those of the Choephori and the Electra of Sophocles. At the end, the Dioscuri appear and condemn Apollo for ordering the murder. As in the Ion, the scenes are not very closely connected, but the main divisions of the play - the recognition of brother and sister, the death of Aegisthus, and the murder of Clytaemestra - do not form sections as distinct as in the Hippolytus. Rather, as in the Ion, such an arrangement is. artificial.

$$
1634-683 .
$$$$
2702-705 \text {. }
$$ 
The Iphigenia in Tauris is similar in structure. On the whole it possesses unity. As a play of romantic adventure in a distant land, it is very charming and far surpasses the Ion and the Electra. There may be a slight touch, but only a slight one, of the melodrama which becomes so prominent in later plays.

The Helena is the most romantic of Euripides' plays and the lightest, but it has not the careful balance of the Iphigenia in Tauris. There Orestes and Iphigenia were both of equal importance. Here Menelaus is not very attractive and is at times almost comic. Structurally also it is not so good. The scene between Helen and Teucer ${ }^{1}$ shows the reputation of Helen among the Greeks. As a prelude and introduction, it is almost as separate as the opening of the Hecuba, but it is an exposition! scene and does not indicate the future. Helen's fears are almost at once quieted by Theonoe. The scene with Theonoe ${ }^{2}$ - forms a slight break between the reunion of husband and wife and their escape from the power of Theoclymenus. The effect of the play is good and an impression of unity is given, largely because of the phantom-Helen and the frivolous character given by Theonoe to the conflict of Hera and Aphrodite, who seem not powerful goddesses but mere fairies.

The Hypsipyle, of which large fragments have recently been discovered, belongs to the same period. Although we do not know all the details of the plot, we can see the general outlines. Hypsipyle, as a slave of Eurydice, cares for the baby Archemorus. Her two sons, whom she has not seen since they were babes, while searching, happen to meet her and ask for hospitality. Of course there is no recognition on either side. She takes them into her mistress's house. Meanwhile Amphiaraus comes and asks for water for the sacred rites. While Hypsipyle guides him to the spring, a serpent kills Archemorus. In terror, the unhappy slave tries to escape, but she is captured by the two young men and taken back to Eurydice, who wishes

$$
168-163 .
$$$$
2 \text { 865-1029. }
$$ 
to slay her. Amphiaraus returns, saves her, and proclaims funeral games in honor of the dead child. Later he unites Hypsipyle with her two sons, and Dionysus appears as deus ex machina, probably to confirm Amphiaraus' action. The Hypsipyle is another romantic drama with almost melodramatic variation in the fortunes of the main characters. Still, interest centres in Hypsipyle and her sons, so that the play has unity in the same sense as the Ion and the Iphigenia in Tauris.

The Phoenissae is a wonderful example of inclusion, since it touches the whole Theban cycle. There are three main strands: (1) the fate of Thebes, especially prominent in the view from the walls (88-201), the preparations and the battle (690-1199), and the lament for Menoeceus (1308-1334); (2) the fate of the brothers, especially prominent in the meeting (261-637) and the combat (1202-1282, 1335-1529); (3) the fate of Oedipus (1530-1763). Probably the representation of Oedipus and Jocasta as alive at the time of the expedition of Polynices was an invention of Euripides. The Hypothesis gives a good criti-

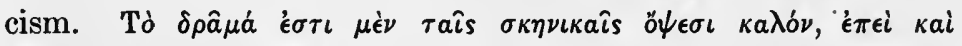

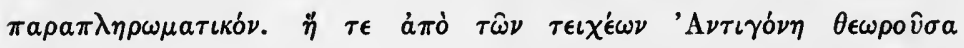

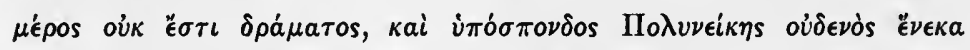

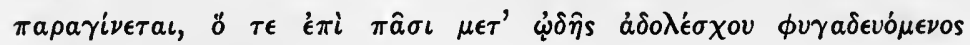

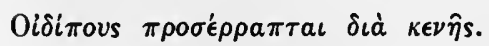

"The pleasure of witnessing this drama must have depended on a knowledge of much literature now lost; happily we possess enough to make most of the scenes alive." 1

There are inconsistencies, especially in the final scene, and many critics have claimed to find much interpolation in it. ${ }^{2}$ The play seems more coherent than the Troades. While this is due to our better knowledge of the sources, the subject has more inherent unity. Structurally it is more involved than

1 Sheppard, Greek Tragedy, p. 144.

2 Cf. Wilamowitz, Drei Schlußscenen, Sitzungsbericht d. kgl. Preuss. Akad. d. Wiss. zu Berlin, 1903, p. $587 \mathrm{ff}$. 
the Troades, but it has the same mixture of epic and dramatic qualities.

The Orestes, the last of the Greek dramas that belong in this series, is almost pure melodrama. The plot is full of the unexpected and the play has as much unity as is consistent with it. To point out merely one neglect of probability, the prologue shows Orestes very ill, but he suddenly recovers and goes off to the assembly. This play marks the lowest level which the art of Euripides reached, as far as we can judge.

It is well for the poet that this was not his last work. He left Athens and during his residence in Macedon, he wrote the Bacchae, an unusually vivid and powerful play. The chorus is much more important than in most of his plays and also much more vitally interested in the action than it usually is. Although some of the scenes, as that between Pentheus, Tiresias, and Cadmus, ${ }^{1}$ are somewhat loosely connected, yet these, like the opening scenes of the Agamemnon, show the atmosphere of the piece and illustrate the ever increasing sin of Pentheus. There is more action in this than in the Septem, but the spirit of the play is almost Aeschylean rather than Euripidean. It is a true lyric drama of the old type.

The Iphigenia in Aulide is another play of the same style and shows that Euripides' art had definitely entered a new period. The play has unity and it shows traces of the lyric character of the works of Aeschylus. Agamemnon's position and the atmosphere of the play are presented in 1-589. It is as impossible to define subdivisions in the play as it is in the plays of Aeschylus. Structurally this is one of the most satisfactory dramas of Euripides. The melodramatic note is absent and the romantic elements are unusually pleasant. The character of Iphigenia, the willing victim, is, in spite of Aristotle's curious judgment, worthy of a great lyric drama.

I do not think that the Rhesus is spurious.

1 170-369. 
"It is a young man's play, full of war and adventure, of spies in wolf-skins and white chargers and gallant chivalry. That is not much like the Euripides whom we know elsewhere; but his mark is upon the last scene, in which the soldiers stand embarrassed and silent while a solitary mother weeps over her dead son. The poetry of the scene is exquisite; but what is most characteristic is the sudden flavour of bitterness, the cold wind that so suddenly takes the heart out of joyous war." 1

The structure of this piece is interesting, as it is the only extant tragedy based on an extant piece of epic poetry. The play falls into three divisions: (1) 1-263, the mission of Dolon; (2) 264691 , the reception and death of Rhesus; (3) 692-996, the accusation of Hector by the charioteer and the appearance of the Muse. There is a kind of tripartite division, but this is rather of the species found in the Alcestis than of that in the Hippolytus, since in the plays of the period of the latter, the parts are less closely connected. The first section serves rather as a preparation for the rest of the drama than as a distinct and independent division or as an illustration of the theme. Throughout the Rhesus, Hector is the main character, as he is prominent in the three sections. The structure may seem crude, but the play well shows the poet's peculiar use of his material. He has followed Iliad $\mathrm{X}$ closely except in regard to the foundation of the cult of Rhesus. There was such a cult in Thrace. ${ }^{2}$ Perhaps this was connected with the play in imitation of the usage of Aeschylus, who delights in ending his trilogies with some "foundation." In view of the structure of the Rhesus, we need not follow Wilamowitz ${ }^{3}$ in rejecting it as a work of Euripides. Our knowledge of the lost plays is too scanty to allow us to say that no dramas prior to the Andromache contained a deus ex machina. The Rhesus, then, seems a work of the first period of Euripides' activity.

${ }^{1}$ Murray, Euripides and His Age, p. 70.

2 Rohde, Psyche 5 , Vol. I, p. 161 N.

${ }^{3}$ Analecta Euripidea, p. 157. 
The Cyclops is the only extant satyric play of Euripides. This follows closely Odyssey IX with such changes as are necessary to fit it for the stage. The chorus of Satyrs, except in the prologue and parodos, is of slight importance, as it excuses itself whenever there is need of action. Since the play is a dramatization of a story which possesses perfect unity, it could hardly fail to show the same quality. In general the Cyclops seems to be of the same period as the Medea; but because of our lack of definite information and our ignorance concerning the satyric drama as a whole, it is useless to discuss the date. The ending, a threat of the Cyclops against Odysseus, ${ }^{1}$ is an adaptation of Odyssey IX, $480 \mathrm{ff}$. Such a conclusion, promising a continued conflict, reminds us of the end of the Septem of Aeschylus. Perhaps another argument for an early date can be drawn from the fact that Euripides makes no effort to gain the sympathy of the audience for the Cyclops.

Various scholars have argued as to Euripides' use of connected trilogies. Krausse ${ }^{2}$ endeavors to prove this in the series Alexander, Palamedes, Troades. Although these are all from the Trojan cycle, he himself admits ${ }^{3}$ that the Palamedes is very loosely connected. He also considers the Oenomaus, Chrysippus, Phoenissae, another instance. ${ }^{4}$ Wilamowitz $^{5}$ holds the same view and connects the absence of a deus ex machina in the Troades and Phoenissae with the fact that they were the concluding plays of trilogies. Although the Septem does not contain a theophany, yet the Oresteia does, and in general we should expect the gods to appear at the end of a connected trilogy rather more frequently than at the end of either of the first two plays. Our evidence on this whole subject is too scanty to give basis for argument.

Krausse also argues that some trilogies are dominated by one idea. Thus in the tetralogy, Cressae, Alcmaeon $\delta \iota \dot{a} \Psi \omega \phi \hat{\imath} \delta$ os,
1 704-707.
${ }^{2}$ Op. cil., p. 183.
s Op. cit., p. 181.
${ }^{2}$ Op. cit., p. 179 ff.
4 Op. cit., p. 184 ff. 
Telephus, Alcestis, the virtues and vices of women are represented. ${ }^{1}$ The weakness of such theorizing can be easily seen.

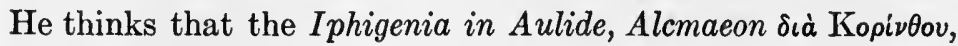
and Bacchae show the relations of parents and children. ${ }^{2}$ Paul Girard ${ }^{3}$ argues for the moral, "Tantum religio potuit suadere malorum." This second interpretation I think mistaken, as the Bacchae seems a sincere glorification of Dionysus and in the Iphigenia in Aulide Calchas may be more responsible for the murder than Artemis. Of course Euripides may have had some general idea which determined his choice of subjects, but we know too little of the methods of grouping used by any of the tragic poets to hazard any conclusions.

Krausse's theory ${ }^{4}$ that Euripides treated prologue and epilogue in such a way as to include the whole substance of an Aeschylean trilogy will be discussed later. It will suffice here to say that it seems impossible to accept his views in all details.

We can now review the methods of Euripides. In each of the four periods into which Wilamowitz ${ }^{5}$ divides the poet's activity, we find a definite style of composition. In the first period (454-430 в.c.), traces of a tripartite division are hardly definite but are clearest in the Rhesus. The other plays aim more at unity of action. If the Rhesus and the Cyclops both belong here, it is interesting to see how closely Euripides followed epic tradition in theme and treatment with strong tendencies to strict unity.

In the second period (430-416 B.c.), he abandoned quite frankly his search for unity and aimed to produce plays each containing several actions more or less closely connected. Early in this period, in the Hippolytus, we see the whole well articulated and approximating the form of an Aeschylean trilogy.

${ }^{1}$ Op. cit., p. 188.

2 Op. cit., p. 188.

${ }^{3}$ La trilogie chez Euripide, Revue des études grecques, Vol. XVII, p. $175 \mathrm{ff}$.

${ }^{4}$ Op. cit., p. 48.

s Ibid., p. 172. 
In other plays, there is no attempt at close connection of the different parts.

In the third period (415-408 в.c.), Euripides aimed rather to produce a thrilling effect. His plays contain much adventure and melodrama. They often seem to have been written to appeal to the mass of the people who were the real judges in the dramatic contests. Unity here is gained by the presentation of a small number of characters in whose fate the audience became interested. Here belongs also the Troades, a play based on the lyric tradition, effective without unity, and the Phoenissae, a summary of Theban legend.

In the fourth period (407-406 B.c.), Euripides returned to the older type of drama and achieved unity better than he had ever done. The aged man received fresh vigor from his life in Macedonia and was enabled to surpass in beauty any of his earlier work now extant.

What then is the record of the formal development of Greek tragedy? Aeschylus composed mainly in trilogies, groups of plays treated as acts of still greater dramas involving generations or ages. The Persae seems to be an independent play with strict unity. Indeed most of his plays show strict unity, although the lyric and descriptive elements predominate.

Sophocles abandoned the use of the trilogy and emphasized the delineation of character. He usually attained unity in structure, although he at times obscured it by depicting too carcfully a subordinate character and thus shifting the centre of intcrest. In the Oedipus Coloneus, however, he adopted the methods of Euripides.

Euripides never attained such perfeet unity as Sophocles, for he did not seek it. He often makes wonderful characterstudies, but like Aeschylus he is more interested in the story. He freely adopts the older forms of tragedy and shows the influence of epic elements in his structure, with the result that his plays often seem poorly constructed. 
Tragedy commences its career as a union of choral songs and dialogues. The individual scenes become progressively more subservient to the idea of the whole until Euripides appears. He allows the chorus to diminish and he rejects much of the technique of Sophocles. He puts into one play enough material for an Aeschylean trilogy. However he varies his methods, his plays always seem in a way dramatized epics, but he never

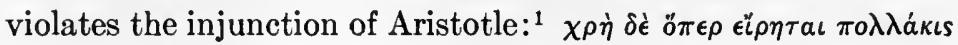

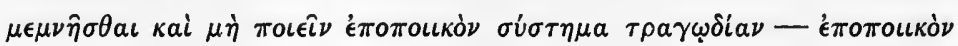

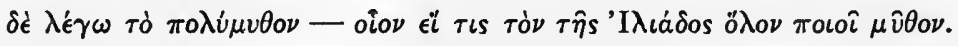
Then at the end the old spirit of tragedy blazes up, and in the swan-song of Greek tragedy we feel "the spirit of the days that are no more." There our record ends.

1 Poetics, p. 1456 a $10 \mathrm{ff}$. 


\section{CHAPTER II}

THE PROLOGUES AND EPILOGUES OF EURIPIDES

IN the Ranae, $945 \mathrm{f}$., Aristophanes represents Euripides as boasting of his prologues:

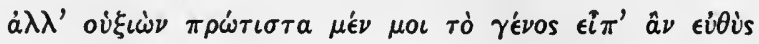

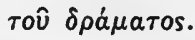

Prof. Murray ${ }^{1}$ supposes that Euripides had returned to a form found in the primitive drama, a solemn address by a sacred or mysterious figure. Whatever the cause may be, it seems as if Euripides put too much information into his prologues, even if some of those now extant show signs of interpolation.

Krausse ${ }^{2}$ says that in his prologues and epilogues, Euripides touches material which Aeschylus would have used for the other plays of the trilogy. The first speech of the prologue of the Electra ${ }^{3}$ reviews the expedition to Troy, the murder of Agamemnon, and the fate of his children. In the epilogue, ${ }^{4}$ the Dioscuri order the marriage of Electra and Pylades and prophesy the acquittal of Orestes at Athens. Thus the poet reviews in one play the material of the Oresteia.

A long account in strict form is seen in the opening of the Hecuba, Supplices, Hercules Furens, Ion, Electra, Iphigenia in Tauris, Helena, Phoenissae, Orestes, and Bacchae. The Archelaus, ${ }^{5}$ the Melanippe $\dot{\eta} \sigma o \phi \dot{\eta}^{6},{ }^{6}$ and the Phrixus ${ }^{7}$ and perhaps others of the lost plays began thus.
1 Ritual Forms, p. 361 ff.
3 1-53.
- Frag. 228.
2 Op. cit., p. 48.
- 1238-1291.
- Ibid., 481.
7 Ibid., 819. 
Examples of such a usage in the works of Aeschylus naturally occur in the opening plays of the trilogies, but we must remember that Aeschylus often uses lyric metres where Euripides employs trimeters. The parodos of the Agamemnon ${ }^{2}$ describes in beautiful poetry the events leading up to the Trojan expedition and the sacrifice of Iphigenia. Less good examples, because of their closer connection with the plot, are the parodoi of the Supplices, ${ }^{2}$ containing the account of the voyage of the maidens to Argos, and of the Persae, ${ }^{3}$ reviewing the expedition of Xerxes. In this latter case the foreign names lend an air of remoteness. In the Prometheus Vinctus, Prometheus after the departure of his persecutors breaks his long silence and in iambic trimeters tells the chorus of his service to Zeus during the revolt of the Titans and of his theft of fire. ${ }^{4}$ Finally the Eumenides, although the last play of a trilogy, contains a very apposite passage, the description of the successive masters and the present cults of Delphi. ${ }^{5}$ This is used to show the relation of the older and younger deities.

Sophocles uses such narratives sparingly. Although we might cite Trachiniae 1-48, a review by Deianira of her marriage to Heracles and of her subsequent life, and Electra $23 \mathrm{ff}$., Orestes' account of the oracle of Apollo in regard to vengeance, such cases are very unimportant and hardly deserve mention.

The form as found in the Iphigenia in Tauris is then a development of Aeschylean usage. Thus, much as the chorus in the parodos of the Agamemnon describes the Trojan war, Iphigenia reviews the history of her race from the time of Pelops to her own sacrifice at Aulis, and then tells her dream about Orestes.

The situation at the end is less clear. In the Eumenides, Orestes promises to Athens the eternal friendship of Argos, ${ }^{6}$
1 104-257.
3 1-64.
5 1-33.
2 1-18.
199-243.
6 754-777. 
and Athena declares the court of the Areopagus permanent. ${ }^{1}$ Because of his use of the trilogy, it was not so necessary for Aeschylus to employ long concluding narrations. Yet the Septem ends in an unresolved conflict and the Persae with a mourning procession. So, too, in the Trachiniae of Sophocles Heracles is borne off to Oeta for burning, and in the Oedipus Coloneus the daughters of Oedipus leave for Thebes in an endeavor to reconcile their brothers.

The Greek drama, drawing its themes from the epic cycle, frequently found it necessary (as indeed all drama does) to leave conflicts unresolved. The Cyclops is a good example. On the Athenian stage, the Cyclops could not carry out his threat to sink the ship of Odysseus with rocks, and so the blinded giant says that he will do it.

We can now see in what sense we can accept Krausse's theory. A play of Euripides in its prologue and exodos often does contain all the material of an Aeschylean trilogy. Still, as such narrations are found even in plays which approximate the trilogy-form, we must not press too far arguments from extent of material. In his historical preludes, Aeschylus is less formal than Euripides, but the methods of the two men are sufficiently similar to suggest that the younger man had revived the custom of the older author.

It is easy to see the cause of Aristophanes' ridicule. Aeschylus had veiled his account with beautiful poetry, or had incorporated it within the play. Euripides, in his desire for clearness, his love of rhetoric, and his need of brevity, made a set form for this recital and placed it at the very opening of the play. The use of such a prologue may have been a return to a primitive form, but it seems largely due to the influence of Aeschylus and to Euripides' own modification of the forms of his predecessor.

In the earlier plays, as the Medea, the prologue is less $1681-710$. 
schematic and contains less material foreign to the theme of the play. Well within the second period, we find more formal speeches with more emphasis on genealogy. In the third period, the form of the Iphigenia in Tauris is typical and we find this also in the Bacchae.

It seems as if Euripides must have recognized the artistic weakness of this form of exposition, unless he felt it fitting because of the epic elements in the drama. In this connection, it is significant that the two dramas based on extant epic sources are probably from a time early in his career. Yet, in spite of the justification of epic usage, the constant tendency to this mannerism may be thought excessive. Certainly Aristophanes wearied of it and satirized it as a special achievement of Euripides. 


\section{CHAPTER III}

\section{THE PARODOS}

In the structure of the parodos, Euripides again follows Aeschylus rather than Sophocles. He does this not only in the metrical structure but also in the contents and the relation to the drama as a whole. Of course, as the parodos is largely lyric, we must expect it to be shorter and less splendid in the plays of Euripides than in those of Aeschylus, but we shall find that the younger poet has arranged the members in the same way as the elder did.

\section{The Structure of the Parodos}

Aeschylus treats the parodos in some plays so that the chorus enters in confusion and haste, a factor which varies the composition of the song. Usually, however, the parodos consists of a series of anapaests followed by several strophes and antistrophes.

We must allude here to an important discussion. What is the parodos? Is it the whole first song of the chorus or the first song of the whole chorus? Freericks ${ }^{1}$ argues for the second definition and accordingly supports the corresponding reading in Aristotle, Poetics, p. 1452 b 22. In discussing the opening of the Supplices, he maintains that the anapaests (1-39) form the prologue, the series of strophes and antistrophes (40-111), the parodos, and finally the strophic series with ephymnia (112-175), the first stasimon. Prof. Tucker ${ }^{2}$ considers the anapaests (1-39) as parodos and the whole lyric section (40-175) as the first stasimon. He continues:

1 De Aeschyli Supplicum choro, p. 22. 2 Supplices, p. xxxvi. 


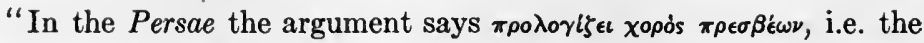
anapaestic $\pi \dot{a} \rho o \delta o s$ is itself a $\pi \rho b \lambda$ 入osos. In Sophocles' Electra there is

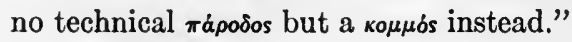

Wecklein ${ }^{1}$ apparently considers $1-175$ as the parodos. The dispute as to the application of the term will, I think, make it clear that in my analysis of the parodoi in the extant plays, I am not seeking to destroy all semblance of order in this part of the drama.

I shall consider the parodos to be that choral part of the play which follows an iambic prologue, if one exists, or else that which opens the play. It consists of anapaests or lyric metres or both, and is followed usually by iambic, trochaic, or anapaestic metres. It is only in some plays of Euripides that this last point will perhaps be troublesome. The following is an analysis of the parodoi in the extant plays of Aeschylus.

Supp. 1-175 1-39 anapaests

40-111 5 strophic systems

112-175 3 strophic systems with ephymnia

Pers. 1-149 1-64 anapaests

65-139 6 strophic systems

140-149 anapaests

Sept. 78-180 78-107 astrophic section

108-180 3 strophic systems

P. V. 188-194 88-127 anapaests and iambics (spoken by Prometheus)

128-194 2 strophic systems sung by chorus with the strophes separated by anapaestic speeches of Prometheus

Ag. 40-257 40-103 anapaests

104-139 strophic system

140-159 mesode

160-257 5 strophic systems

1 Äschylos Orestie, p. 34. 
Ch. 22-83 22-74 3 strophic systems

75-83 epode

Eum. 244-275 244-253 iambic trimeters

254-275 astrophic section

Our knowledge of the lost plays is naturally very slight, but a very few of the fragments can be mentioned here.

Frag. 131 (Myrmidones)

4 anapaests which Schol. Aristoph. Ran. 992, and Harpocration, p. 159. 8, cite as the opening of this play. The Myrmidones is conjectured to be the first play of the trilogy, Myrmidones, Nereides, Phryges. ${ }^{1}$

Frag. 190-192 (Prometheus Solutus) 3 anapaestic fragments which have been preserved in various writers. Even if we were not told it, frag. 190 would be seen to be from the parodos.

Frag. 57 (Edoni) This fragment of 11 anapaestic lines may be placed here, although we have no proof that it is from the parodos. The Edoni, we may remark, was the first play of the Lycurgeia.

We find then the normal form of the parodos to be a series of anapaestic verses preceding a lyric section. This is the form

1 Nauck 2, p. 42. 
found in the Supplices, Agamemnon, Persae, and apparently in the Myrmidones and the Prometheus Solutus. Except the last, all of these are the first plays of trilogies or independent dramas. The Prometheus Vinctus shows a monologue and then a dialogue in which the actor uses anapaests and the chorus lyric metres. The Choephori alone shows simple lyric metres. In the Septem and the Eumenides, the astrophic form well suits the effective but rapid and disordered entrance of the chorus. It will also be noticed that both of these are the concluding plays of trilogies.

Let us now turn to the plays of Sophocles.

Ant. 100-154 100-154 2 strophic systems with strophes separated by anapaestic systems (all sung by chorus)

Aj. 134-200 134-171 anapaests

172-192 strophic system

193-200 epode

Tr. 94-140 94-130 2 strophic systems

131-140 epode

O. R. 151-215 151-215 3 strophic systems

El. 86-250 86-120 anapaests of Electra

$\begin{array}{ll}\text { 121-232 } 3 \text { strophic systems } & \begin{array}{l}\text { each part divided } \\ \text { between chorus }\end{array} \\ \text { and Electra }\end{array}$

Phil. 135-217 135-217 3 strophic systems and 3 anapaestic systems rendered as follows:

str. 1 chorus

syst. 1 Neoptolemus

ant. 1 chorus

syst. 2 Neoptolemus and chorus

str. and ant. 2 chorus

syst. 3 Neoptolemus

str. and ant. 3 Neoptolemus and chorus. 
O. C. 117-253 117-206 2 strophic systems and 3 anapaestic systems rendered as follows:

str. 1 chorus

syst. 1 Oedipus and chorus

ant. 1 chorus

syst. 2 Oedipus and Antigone

str. 2 chorus, Oedipus, and Antigone

syst. 3 Oedipus

ant. 2 Oedipus, Antigone, and chorus

207-253 astrophic section of Oedipus, Antigone, and chorus

The structure of the parodos in the Ichneutae cannot be certainly outlined because of the fragmentary condition of the text.

Perhaps we might assign frag. 248, 249 to the parodos of the Inachus and frag. 491, 492 to the parodos of the Rhizotomi, but we have no knowledge as to the position of these anapaestic fragments.

We see then that Sophocles on the whole used a simpler form than Aeschylus. Two plays (Oedipus Rex and Trachiniae), like the Choephori, have parodoi composed only of lyric systems. The Ajax alone contains introductory anapaests chanted by the chorus. In the Electra, one character uses them before the entrance of the chorus. They are arranged as system and antisystem unlike the use in $P . ' V .88-127$. The rest of the parodos is a kommos in which Electra and the chorus share each strophe or antistrophe. In the Antigone, the anapaestic systems, inserted between the strophes, are also sung by the chorus. This arrangement is found also in the Philoctetes and the Oedipus Coloneus, but in these plays, actors and chorus divide up each section into a regular dialogue. These plays, however, are from a late period in Sophocles' career.

Now let us look at the plays of Euripides. 
Cycl. $41-81$

Alc. 77-135

Med. 96-212

Her. $73-110$

Hipp. 121-169

And. 117-146

Hec. 59-215
41-62 strophic system with ephymnia 63-81 epode

77-85 anapaests

86-111 strophic system (in which 93-97 and 105-111 are corresponding anapaests)

112-131 strophic system

132-135 anapaests

96-130 anapaests of Medea and nurse

131-147 anapaests of chorus, nurse, and Medea

148-159 184$\}$ strophic system

160-172 anapaests of Medea and nurse

185-203 anapaests of nurse

204-212 epode

73-74 iambic trimeters

75-110 strophic system containing many iambic trimeters (a conversation between the chorus, Iolaos, and the herald, the last only in the antistrophe)

121-160 2 strophic systems

161-169 epode

117-146 2 strophic systems

59-97 anapaests of Hecuba

98-153 anapaests of chorus

154-215 strophic system and mesode (str. Hecuba mesode Hecuba and Polyxena ant. Polyxena

The verses are anapaestic with very free substitution of spondees, etc. - melic anapaests) 
Supp. $42-87$

H. F. 107-137

Ion $82-237$

Tro. $98-229$

El. 112-212

I. T. $123-235$

Hel. 164-251

Phoen. 202-260

Or. 140-207

Bacch. 64-169
42-87 3 strophic systems

107-137 strophic system

82-111 anapaests of Ion

112-143 strophic system with ephymnia of Ion

144-183 melic anapaests of Ion

184-237 2 strophic systems of chorus (in ant. 2, Ion speaks melic anapaests which have no corresponding lines in the strophe)

98-152 anapaests of Hecuba

153-196 strophic system of Hecuba and chorus

197-229 strophic system of chorus

(a kommos of melic anapaests)

112-166 2 strophic systems with mesodes of Electra

167-212 strophic system of chorus and Electra (each section divided between the two)

123-235 melic anapaests of Iphigenia and chorus (the metre is almost spondaic)

164-166 dactylic verses of Helen

167-251 two strophic systems and epode (Helen and the chorus sing alternate strophes)

202-225 strophic system

226-238 mesode

239-260 strophic system

140-207 2 strophic systems divided between the chorus and Electra

64-72 proöde

73-134 2 strophic systems

135-169 epode 

I. A. 1-48, 115-302 $\left.\begin{array}{c}1-48 \\ 115-163\end{array}\right\} \begin{gathered}\text { anapaestic prologue of Agamem- } \\ \text { non and servant }\end{gathered}$

164-302 choral song, part of which, at least, is in strophic systems

Rh. 1-51

1-22 anapaestic prologue of chorus and Hector

$\left.\begin{array}{c}23-33 \\ 41-51\end{array}\right\}$ strophic system of chorus

34-40 anapaests of Hector

Hypsipyle 3(1) 2 strophic systems sung as follows:

str. and ant. 1 Hypsipyle

str. and ant. 2 chorus

The order is - str. 1 , ant. 1 , str. 2, ant. 2

(The treatment is really the same as in El. 167-212)

Frag. 773 11. 19-58(Phaethon) 19-50 2 strophic systems 51-58 epode

Frag. 114 (Andromeda) This play opened with anapaests, as we learn from Schol. Aristoph. Thesm. 1065

Frag. 229 (Archelaus) This anapaestic fragment may possibly be from the parodos

Frag. 472 (Cretes) This is apparently from the parodos ${ }^{1}$ Frag. 592-594 (Pirithous) Perhaps these are from the parodos

If we group these without separating parodoi with proödes, mesodes, or epodes, we obtain the following results. Eight plays (Cyclops, Hippolytus, Andromache, Supplices, Hercules Furens, Phoenissae, Bacchae, Phaethon) have a parodos of lyric metres only. One (Alcestis) has anapaests at the beginning and corresponding anapaests within strophe and antistrophe. One (Cretes) apparently had anapaests at the beginning. Two

1 Cf. 1.4. 
(Helena, Hypsipyle) allow actor and chorus to sing sections antiphonally. Two (Heraclidae, Orestes) have the form of conversation. Two (Medea, Rhesus) have parodoi in which both actors and chorus use anapaests and then the chorus commences the ode, while the actors continue anapaests. One (Iphigenia in Tauris) has a complete anapaestic parodos in which spondees are very numerous. One (Iphigenia in Aulide) has an anapaestic prologue but a parodos of lyric metres sung by the chorus. Three (Troades, Electra, Ion) have as prelude to the choral song, which is variously treated, anapaests, strophic system, or a mixture of the two. Perhaps the Andromeda also belongs here. Finally, one (Hecuba) has anapaests chanted by an actor, a second series by the chorus, and then an anapaestic kommos of two actors.

I am well aware that this takes a very broad view of the parodos. In the Hecuba, we probably should omit the kommos as we did in the Ajax. ${ }^{1}$ It seems to me no mere coincidence that of nine dramas of Aeschylus, in six the parodos begins with anapaests, and that among the twenty-three of Euripides, nine have anapaests at the beginning or anapaests chanted by an actor and one, a strophic system before the entrance of the chorus. In seven plays, Sophocles has introductory anapaests only twice: in the Ajax, where the form of Aeschylus is followed, and in the Electra, where an actor recites them. Since, furthermore, several of the plays of Euripides with these anapaests come from much the same period, it seems likely that the methods of Aeschylus were the determining or at least an influential factor. In Aeschylus, the chorus might be the protagonist, as in the Supplices. When later it lost this rôle, it was possible for an actor to deliver the anapaests or the opening part of the parodos.

Although the form seen in the Prometheus Vinctus is not used by Sophocles, it occurs in the Medea and the Rhesus. Sir Richard 
$\mathrm{Jebb}^{\mathrm{x}}$ considers the forms of the Prometheus Vinctus, Antigone, and Philoctetes as closely akin, since the lyric parts are intermingled with anapaestic systems, and he holds that this form is quite near that of the Ajax, Persae, etc. There is, however, a striking difference. In the Prometheus, there is a dialogue in which Prometheus regularly uses anapaests and the chorus, lyric strophes. . The parodos of the Antigone, on the other hand, consists of one song by the chorus, and the intermingling seems more artificial. Then, in the Philoctetes and the Oedipus Coloneus, this form of parodos is broken up into conversation. Decharme ${ }^{2}$ assigns the use of dialogue by Sophocles to the influence of Euripides, and rightly. Euripides did not use the Sophoclean form. In the Alcestis and elsewhere, he uses anapaests among the strophes, but in the Alcestis they form part of the strophe and are accordingly answered in the antistrophe, whereas Sophocles inserts them as interludes. Elsewhere when used, they occur in dialogue.

Euripides also follows Aeschylus in not using a song of the whole chorus. The parodos of the Septem opens with a section which seems astrophic.

"It may be, as many scholars from Hermann to Wecklein have thought, that the first part is not antistrophic, but is sung by different individuals in the Chorus, so as to give a better suggestion of the distraction and fright of the women." 3

The same is true of the Eumenides, whether we accept as parodos 140-177 with Detscheff ${ }^{4}$ or 244-275 with Sidgwick. ${ }^{5}$ It seems certain that in the Alcestis, Heraclidae, Supplices, Ion, Troades, the songs also were sung by various members of the chorus. From such an arrangement, it is but a short step to the method used in the Heraclidae and Orestes, where we have real conver-

1 Ajax, p. 31. $\quad 2$ Euripide et l'êsprit de son théatre, p. 483.

3 Sidgwick, Septem contra Thebas, p. 5.

- De tragoediarum Graecarum conformatione scaenica ac dramatica, p. 134.

5 Eumenides, p. 19. 
sation. Apparently Sophocles takes this liberty only in the Oedipus Coloneus.

It is not easy to assign various tendencies to various periods in the life of Euripides. If we disregard the prologue of the Rhesus as suspicious, we still have the parodoi of the Medea and the Alcestis opening with anapaests, and these are from the first period of Euripides' career. The dramas from the end of the second period and the beginning of the third frequently contain anapaestic sections recited or sung by one of the actors before the entrance of the chorus. The dramas of the last period contain parodoi of lyric metres only. The Iphigenia in Aulide, it is true, has an anapaestic prologue - the genuineness of which is often attacked, although it is defended by Weil. ${ }^{1}$

The spirit and apparent form of the parodoi of Euripides differ widely from those of Aeschylus. They are less grand and dignified. Yet here as elsewhere Euripides has modified and freed the devices of Aeschylus, rather than those which he could have taken from Sophocles.

\section{The Cause of the Entrance of the Chorus}

Euripides also follows Aeschylus in the way in which he explains to the audience why the chorus enters. The method of Sophocles is really more artificial, but it is also more artistic. I intend to discuss not the deep psychological bond of union between actor and chorus (as in H. Fries, De conexu chori personae cum fabulae actione) but the mere external cause of the entrance.

In the Supplices of Aeschylus, the chorus is really the protagonist. It enters in its endeavor to escape the sons of Aegyptus. In the Persae, it reviews the size of Xerxes' forces and seeks to speculate how he is faring. In the Prometheus Vinctus, it has heard the noise of the binding of Prometheus and comes

1 Sept tragédies d'Euripide, p. 309. 
in consequence, and in the Solutus ${ }^{1}$ it appears for much the same reason, a desire to see the afflicted man. The chorus of the Agamemnon enters to learn the reason for the unwonted sacrifices. In the Choephori, it announces that it is taking libations to Agamemnon's tomb. In the Eumenides, the Erinyes are tracking Orestes. In the Septem, the chorus rushes to the altars and images of the gods. The parodos of Aeschylus, then, usually tells why the chorus has come.

Sophocles is not so precise. In the Antigone, the chorus heralds the approach of Creon in anapaests ${ }^{2}$ and says that it has come as he ordered. This is not strictly in the parodos. Similarly in the Oedipus Rex, Electra, and Trachiniae, it gives no reason for entrance or at least not in the parodos. In the $A j a x$, it has come to learn of the truth of the rumors about Ajax, although it does not say so directly. In the Philoctetes, the position of the chorus as the sailors of Neoptolemus' ship renders its presence natural without explanation. In the Oedipus Coloneus, it enters in its search for Oedipus. In the Ichneutae, Silenus tells Apollo in iambics, ${ }^{3}$ before the parodos begins, that he has come with his children in hopes of gaining the reward. Sophocles, then, often does not state clearly the reason for the appearance of the chorus. He has a more artistic aim, but at times the chorus does not make any pretence of having a reason for its coming.

Euripides in his love for clearness of exposition returns to the methods of Aeschylus, - nay more, he even renders them more transparent than did his predecessor. In several plays, as the Medea, the Troades, and the Helena, the chorus enters because it has heard the laments of some one of the characters. In another, the Andromache, it comes to sympathize and make peace. In the Alcestis, the Hippolytus, the Orestes, and the Hypsipyle, it enters with a desire to obtain definite knowledge, and we may perhaps place here the Heraclidae, in which it
: Frag. 190.
$2155-161$.
$39 \mathrm{ff}$. 
wishes to learn the cause of the tumult. In the Hecuba and the Rhesus, it comes with information for an actor. In the Supplices, it of course is presenting its petition to Aethra. In the Iphigenia in Aulide, it is merely sight-seeing. In the Electra, it brings an invitation to Electra to attend a religious service. In the Ion, it has accompanied its mistress, Creusa. In the Iphigenia in Tauris, it comes in response to a summons from Iphigenia. In the Phaethon, it is to sing at the wedding. ${ }^{1}$ In the Bacchae, it accompanies Dionysus. In the Cyclops, it cares for the herds of the Cyclops. In the Hercules Furens, in vague words, it says that it has come to sympathize with Amphitryon, and in the Phoenissae it tells how it came to Thebes. We may notice that in all but the Cyclops, Alcestis, Heraclidae, Hippolytus, Hercules Furens, Ion, Phoenissae, Orestes, and Hypsipyle, it definitely explains why it has come, and even of these exceptions, in all except the Cyclops, Hypsipyle, and Phoenissae, the reason for its appearance is more or less clearly indicated.

In the dramas of Euripides, the reason advanced for the entry of the chorus may be of the most unsubstantial and chance character possible, but it is given. Aeschylus, because of the importance of the chorus, often gave a real motive for its appearance. Still the methods of Euripides are a development of the usage of Aeschylus, not of that of Sophocles, whom he perhaps influenced in the Oedipus Coloneus.

1 Frag. 773, 1. 44 ff. 


\section{CHAPTER IV}

\section{THE IAMBIC SPEECHES OF THE CHORUS}

Although in many ways Euripides reduces the importance of the chorus in his plays, yet in one particular he revives some of its former dignity by making it express clearer judgments upon the actors and the actions than it does in the plays of Sophocles. It is less apt to be strictly neutral and purely conventional in its utterances at the end of the long speeches of the actors. Fries ${ }^{1}$ has shown that Euripides connects the chorus with the position of one of the actors more closely than Sophocles, but he has dealt for the most part with the choral songs. We shall here consider the short iambic speeches which are often only one or two lines in length.

As Fries well emphasizes, in some of the plays of Aeschylus the chorus is one of the protagonists. So in the Supplices and the Eumenides, we can hardly conceive of it as a formal deliverer of colorless opinions. Not merely in the choral odes but throughout it stands forth as the champion of a definite position. In the Persae, the chorus is vitally interested in the fate of Xerxes and tells Atossa that it is a body of friendly counsellors. ${ }^{2}$ Such passages then as $787 \mathrm{ff}$. are not merely conventional requests for information to satisfy the spectators, but they are questions of supreme importance to the chorus as well as to Atossa. In the Septem the chorus is on the side of Thebes and advises Eteocles not to meet his brother in battle. ${ }^{3}$ In the Prometheus, it suffers at the end with Prometheus. It wishes to hear Io's story. ${ }^{4}$ In the Agamemnon the long threnos and the

1 De conexu chori personae cum fabulae actione.
2175 .
$3712 \mathrm{ff}$.
419 ff. 
quarrel with Aegisthus ${ }^{1}$ show that the chorus takes a definite stand on the questions at issue. In the Choephori its position is not doubtful, for it persuades the nurse to fetch Aegisthus without his bodyguard. ${ }^{2}$ In the plays of Aeschylus, in the dialogue portions as well as in the odes, the chorus is not neutral but is a helper or a very sympathetic adviser to the actors. In most of the plays, it expresses judgments of which the spectators approve.

In the plays of Sophocles, the chorus is less active. In the Antigone, for instance, it advises Creon to yield to Tiresias ${ }^{3}$ but it previously has submitted to the ruler and in several passages, as $471-472$, it merely states facts without commenting upon them. In the stormy scene between Creon and Haemon, it lacks a definite position and says:

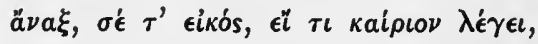

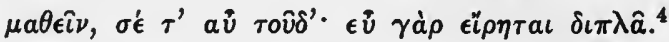

In the Ajax, the chorus composed of Salaminian sailors is closely related to Ajax and is imperilled by his fall. ${ }^{5}$ Yet it tries to moderate the anger of its chief ${ }^{6}$ and during the dispute concerning the funeral to restrain the participants, Menelaus, ${ }^{7}$ Teucer, ${ }^{8}$ Agamemnon. ${ }^{9}$ In the Oedipus Rex, the chorus continues the same policy. It leaves the discovery of the criminal to the god ${ }^{10}$ and attempts to calm Oedipus in the scene with Tiresias ${ }^{11}$ and to prevent trouble with Creon. ${ }^{12}$ Here as in the Antigone the chorus has little personal connection with the protagonist. The same tendency appears in the Electra, where the chorus urges moderation on Electra. ${ }^{13}$ In the Trachiniae also the chorus fails to express any decided views. In the Philoctetes, as in the Ajax, the chorus is formed of sailors subject to one of the
$11407 \mathrm{ff}$.
$2730 \mathrm{ff}$.
- $481 \mathrm{ff}$.
- 1100-1101.
7 1091-1092.
so 276 ff.
8 1118-1119.
$11404 \mathrm{ff}$.
4 724-725.
- 1264-1265.
$12523 \mathrm{ff}$.
${ }^{13}$ 610-611, 1015-1016.
s $900 \mathrm{ff}$. 
actors, yet it contents itself with platitudes, as in its remark to Odysseus:

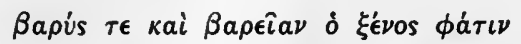

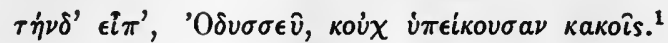

The Oedipus Coloneus differs from the other Sophoclean tragedies extant in this point. The chorus takes a firmer stand on various occasions. It declares boldly in answer to Oedipus' appeal for help:

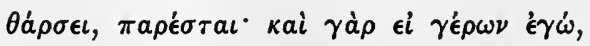

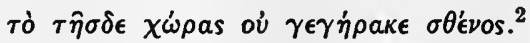

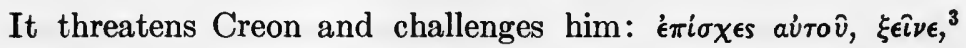
and later condemns Polynices and urges him to leave as quickly as possible. It proves that it spoke the truth in $461 \mathrm{ff}$., when it declared that as Oedipus was to help Athens, it would assist him. In the Ichneutae, the chorus is very important, as a considerable part of the extant portion is a dialogue between Cyllene and the Satyrs, and the latter as the agents of Apollo almost become one of the protagonists of the play. As far then as we can judge from the extant plays, Sophocles uses the speeches of the chorus in a rather colorless manner. The exceptions are the Oedipus Coloneus, the structure of which has been influenced by the plays of Euripides, and the Ichneutae, which is probably the oldest satyric drama extant and the earliest play of Sophocles which has been preserved.

Euripides follows Aeschylus in making the chorus express its opinions more boldly, although the extent to which this is true varies in different plays. In the Bacchae, it is vitally interested in the defeat of Pentheus and censures him at every turn. It condemns the king as impious for his treatment of Cadmus and Tiresias, ${ }^{5}$ it greets the escaping Dionysus, ${ }^{6}$

$\begin{array}{ll}1 & 1045-1046 . \\ 2 & 726-727 .\end{array}$
3856.

4 1397-1398.
5 263-265.

6 608-609. 
in spite of its fear of the ruler, it confesses the power of the god, ${ }^{1}$ and it triumphs at the news of the tyrant's death. ${ }^{2}$ In the Supplices, the chorus, composed of the mothers of the dead chieftains, would naturally not be neutral. It supplements the pleas of Adrastus, ${ }^{3}$ it commends Aethra's intervention, it rebukes the herald, ${ }^{5}$ and rejoices over the Athenian victory. ${ }^{6}$ In the Troades, the chorus of captive Trojan women utters many gnomic sayings, as $608-609$, or speeches referring to its own lot, as 684-685, but it appeals to Hecuba to answer Helen:

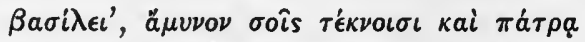

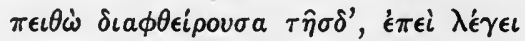

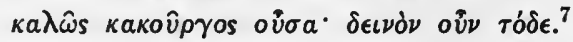

Similarly it appeals to Menelaus to destroy Helen, who has disgraced her sex. ${ }^{8}$ In the Ion, the chorus, composed of the maids of Creusa, is deeply attached to its mistress and condemns the action of Xuthus. It wishes the prosperity of the queen, ${ }^{9}$ it rejoices that Ion wishes to stay at Delphi, ${ }^{10}$ it tells the oracle in defiance of Xuthus' orders, ${ }^{11}$ and it wishes to share the queen's fate, whatever it may be. ${ }^{12}$ In the Heraclidae, the chorus of Athenians does not waver in its views. Without assenting to the speech of the herald, ${ }^{13}$ it approves that of Iolaus and urges the reception of the suppliants, ${ }^{14}$ it refuses to allow the surrender of Iolaus, ${ }^{15}$ and it opposes the murder of Eurystheus. ${ }^{16}$ Indeed it represents the point of view of the Athenians and so is not neutral. In the Medea, the chorus has a definite opinion. It tells Medea that she is acting rightly ${ }^{17}$ and says to Jason that he is doing wrong. ${ }^{18}$ It urges Medea not to kill her children ${ }^{19}$ and again condemns Jason. ${ }^{20}$ In the Hercules Furens,

$1775-777$.

$21031 \mathrm{ff}$.

193-194, 250-252.

- 332-333.

ธ 511-512.

- 731-733;

7 966-968.
8 1033-1035.

- 566-568.

10 648-649.

11760 ff.

$12857-858$.

13 179-180.

14 232-235. 1s 461-463.

$16961 \mathrm{ff}$.

17 267-268.

$18576-578$.

19 811-813.

20 1231-1235. 
the chorus is unreservedly on the side of Heracles, it discusses whether or not it can defend the victims of Lycus, ${ }^{1}$ and later it blames Hera for the madness of Heracles. ${ }^{2}$ In the Iphigenia in Tauris, many of the speeches are colorless, but the chorus promises to help Iphigenia ${ }^{3}$ and attempts to delay the messenger who is reporting the escape to Thoas. ${ }^{4}$ The chorus in the Phoenissae, although composed of strangers at Thebes, does not hesitate to have an opinion as to the merits of the brothers. It praises Polynices, ${ }^{5}$ condemns Eteocles, ${ }^{6}$ and prays for a reconciliation. ${ }^{7}$ In the Orestes, in addition to gnomic sayings, as 542-543, the chorus formally asks Menelaus to help Orestes. ${ }^{8}$ It condemns Helen ${ }^{9}$ and assists Electra in her watch for enemies. ${ }^{10}$ In the Helena, the chorus is friendly to Helen and advises her to consult Theonoe ${ }^{11}$ instead of believing Teucer. ${ }^{12}$ In naive fashion it wishes to hear the plea of Menelaus, ${ }^{13}$ as the chorus in the Prometheus desire to learn about Io's wanderings. ${ }^{14}$ The chorus of the Hippolytus is not very decided in its views, but it approves of Phaedra's plan rather than the nurse's, ${ }^{15}$ and later because of its oath it does not tell of the innocence of Hippolytus. In the Iphigenia in Aulide, the chorus throughout is opposed to the sacrifice of the maiden and pities Agamemnon ${ }^{16}$ and Iphigenia. ${ }^{17}$ It clearly condemns the sacrifice, although it approves Iphigenia's decision to die willingly. ${ }^{18}$ In the Cyclops, the chorus of Satyrs constantly seeks to escape from the Cyclops ${ }^{19}$ and so it naturally sides with Odysseus, and even takes his part against Silenus. ${ }^{20}$ It is willing to assist in the blinding of the monster but it always loses its courage and excuses its inactivity. ${ }^{21}$

$\begin{array}{ll}1 & 252 \mathrm{ff} ., 312-315 . \\ 2 & 1311-1312 . \\ 3 & 1075-1077 . \\ & 1288 \mathrm{ff} . \\ & 497-498 . \\ 6 & 526-527 . \\ 7 & 586-587 .\end{array}$

$1252 \mathrm{ff} ., 312-315$.

2 1311-1312.

3 1075-1077.

$1288 \mathrm{ff}$.

.

$7586-587$.

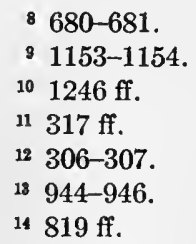


In other plays, however, the chorus does not take so decided a position. In the Alcestis, for instance, the chorus praises Alcestis in such frigid terms that the $\theta \epsilon \rho a$ ra nant. ${ }^{1}$ The same calm character is seen in $326-327$ and the scene between Pheres and Admetus. ${ }^{2}$ It is surprised at the reception of Heracles by Admetus. ${ }^{3}$ In the Andromache, the chorus is very frigid. In the scene between Peleus and Menelaus, it urges moderation ${ }^{4}$ much in the Sophoclean fashion. It reveals to Peleus the plot of Orestes ${ }^{5}$ but on the whole its function is rather slight. Although the chorus of the Hecuba is composed of captive Trojan women, most of their remarks are formal, as in the scene between Odysseus and Hecuba. ${ }^{6}$ In the Electra, the chorus is quite neutral. In some passages, as 401-403, it sympathizes with Electra, but its comments ${ }^{7}$ on Clytaemestra's speech are a good illustration of the gnomic and formal attitude which it assumes. In the Rhesus, too, the chorus does little more than present formal comments on the action, as in $804 \mathrm{ff}$., where it briefly sums up the situation and shows the innocence of Hector.

Unlike Sophocles, then, Euripides often connects his chorus in some degree with one of the actors throughout the play. It takes a definite stand and often tends to express the poet's view of the true ethical import of the drama. Prof. Murray ${ }^{8}$ says of the chorus:

"It also carries on, by the mouth of its Leader, a certain amount of ordinary dialogue with the actors. Its work here is generally kept unobtrusive, neutral and low-toned. When a traveller wants to ask his way; when the hero or heroine announces some resolve, or gives some direction, the Leader is there to make the necessary response. But only within certain carefully guarded limits. The Leader must never become a definite full-blooded character with strongly personal

$1150 \mathrm{ff}$.

611-740.

$3551 \mathrm{ff}$.

4 $642-644,691-692,727-728$.
- $1047 \mathrm{ff}$.

6 296-298.

7 1051-1054.

- Euripides and his Age, p. 235 f. 
views. He must never take really effective or violent action. $\mathrm{He}$ never, I think, gives information which we do not already possess or expresses views which could seem paradoxical or original. He is an echo, a sort of music in the air. . . . At times, in these dialogue scenes, an effect is obtained by allowing the Chorus to turn for a moment into ordinary flesh and blood."

This is true in the main, but Euripides' choruses very often express a definite opinion as to the justice of one or more of the most prominent characters in the play.

Herein Euripides has followed the usage of Aeschylus, in whose plays the chorus is usually connected with the actors. Sophocles diminishes the function of the chorus until it interferes in the dialogue in a colorless way, and in the desire to keep it neutral he neglects any relationship which it may have with one of the characters. Euripides, who revives the older method, develops all means of connecting the chorus and the characters and also indicates, through the iambic speeches of the coryphaeus, his own attitude toward the moral problems underlying the play. It is true that such iambic speeches are more frequent in the dramas of Euripides than in those of Aeschylus, since the latter uses the lyric metres more extensively, but it is clear that in his use of such speeches, the model of Euripides was not Sophocles but Aeschylus. 


\section{CHAPTER V}

\section{THE ANAPAEST}

IN chapter III, we have seen some similarities in the use of the anapaest by Aeschylus and Euripides. Let us see now if in other ways also the two poets agree in their use of this metre.

Prof. Smyth, ${ }^{1}$ in a classification of the occurrences of this metre, arranges the examples as (1) anapaests of parodos and march; (2) semimelic anapaests; (3) melic anapaests. The third division consists usually of short sections of one or two lines, generally part of a strophe, although in the plays of Euripides we do find long passages in this metre. This class, from its association with other metres and its incorporation in odes, concerns us less intimately and we shall mention only some of the more striking cases of it. In my grouping, I shall follow in general Prof. Smyth's divisions, but I shall not mention the passages which I have treated in chapter III.

1. (a) Anapaests at entrance of character - Pers. 150-154 (of Atossa), 909-921 (spoken by Xerxes and the chorus), Sept. 861-874 (of Antigone and Ismene), P. V. 286-299 (spoken by Oceanus), 561-565 (spoken by Io), Ag.782-809 (of Agamemnon).

(b) Anapaests at end of episode or as prelude to stasimonSupp. 625-629, Pers. 532-547, 623-632, Sept. 822-831, P. V. 279-285, Ag. 355-366, Eum. 307-320.

(c) Anapaests at departure of character - P. V. 877-886 (spoken by Io), Ag. 1331-1342 (of Cassandra), Ch. 855-868 (of Aegisthus).

1 Notes on the Anapaests of Aischylos, Harvard Studies, Vol. VII, p.139. 
(d) Anapaests at ending of play - Sept. 1059-1084, P. V. 1040-1093, Ch. 1065-1076.

(e) Miscellaneous anapaests (interludes) - Supp. 966-979, Ch. 719-729.

2. Semimelic anapaests - threnoi and anapaestic systems mixed with lyric passages - Ag. 1448-1576 (1462-1467, 1475$1480,1497-1504,1523-1529,1551-1559,1567-1576$, the speeches of Clytaemestra in kommos), Ch. 306-479 (306-314, 340-344, $372-379,400-404,476-478$, speeches of the chorus in threnos), Eum. 916-1020 (927-937, 949-955, 968-975, 988-995, 10031013, the speeches of Athena).

3. Melic anapaests - Pers. $694-696=700-702$, Ch. $1007-$ $1009=1018-1020$.

Sophocles uses the anapaest less extensively.

1. (a) Ant. 155-161 (of Creon), 376-383 (of Antigone), 526-530 (of Ismene), 626-630 (of Haemon), 800-805 (of Antigone), 1257-1260 (of Creon), Phil. 1409-1417 (spoken by Heracles).

(b) No examples.

(c) Ant. 929-943 (spoken by chorus, Creon, and Antigone).

(d) Ant. 1347-1353, Aj. 1402-1420, Tr. 1259-1278, El. 1508-1510, Phil. 1445-1471, O. C. 1751-1779 (the first three passages contain reflections on the action of the plays).

(e) $A j .1163-1167$.

2. Ant. 806-882 (817-822, 834-838, speeches of chorus), $A j$. 201-262 (201-220, speeches of Tecmessa and chorus, 233-244, 257-262, the speeches of Tecmessa), Tr. 971-1042 (971-1003, speeches of Hyllus, old man, and Heracles), O. R. 1297-1368 (1297-1312, speeches of chorus and Oedipus).

This shows the relative unimportance of the anapaest in Sophocles' plays. At the conclusion of a drama, it is often used to express a moralizing comment. In the semimelic passages, it is retained, but even here the proportion of anapaest to lyric is much smaller than in the work of Aeschylus. Only 
in the Antigone is the entrance of characters often heralded in this metre. In these cases, there is a loss in content as well as length, since the treatment is rather formal, a mere announcement and a simple comment upon the character entering.

Now let us consider the usage of Euripides.

1. (a) Alc. 28-37 (spoken by Thanatos), 238-243 (of Admetus and Alcestis), Hipp. 170-266 (170-175 of nurse, 176-266 spoken by nurse and Phaedra), 1282-1295 (spoken by Artemis), 1342-1369 (spoken by chorus and Hippolytus), And. 494-500 (of Andromache), 1166-1172 (of the body of Neoptolemus), 1226-1230 (of Thetis), Supp. 794-797 (of the bodies of the slain chiefs), 980-989 (of Evadne), 1114-1122 (of the children with the bones of the chiefs), H. F. 442-450 (of Amphitryon and Megara), Ion 1244-1249 (of Creusa), Tro. 230-234 (of Talthybius), 568-576 (of Andromache), 1118-1122 (of the body of Astyanax), 1251-1259 (of the burning of Troy), El. 988-997 (of Clytaemestra), 1172-1176 (of the matricides), 1233-1237 (of the Dioscuri), I. T. 456-466 (of the captive Orestes and Pylades), Phoen. 1480-1484 (of the bodies of the brothers), Or. 348-355 (of Menelaus), 1013-1017 (of Pylades), I. A. 590-606 (of Clytaemestra), Rh. 379-387 (of Rhesus), 882-889 (of the Muse), Hyps. iv, 5(3)10-14 (of Amphiaraus), frag. 773 (Phaethon), 11. 59-65 (of the king, herald, and Phaethon).

(b) Cycl. 483-494.

(c) Alc. 741-746 (of the funeral), Med. 357-363 (of Creon), 759-763 (of Aegeus), Tro. 782-798 (spoken by Talthybius and Hecuba).

(d) Her. 1053-1055, Hipp. 1462-1466, Hec. 1293-1295, Supp. 1232-1234, H. F. 1427-1428, El. 1292-1359, I. A. 1627-1629, Rh. 993-996, frag. 446 (Hippolytus). Ending A - Alc. 11591163, Med. 1389-1419 (1415-1419, ending, except 1415), And. 1284-1288, Hel. 1688-1692, Bacch. 1368-1392 (1388-1392, ending). Ending B $-I$. T. 1490-1499 (1497-1499, ending), Phoen. 1764-1766, Or. 1682-1693 (1691-1693, ending). 
(e) Med. 1081-1115, Her. 288-296.

2. Alc. 244-279 (273-279, speech of Admetus in threnos), 861-934 (861-871, 878-888, 895-902, 912-925, the speeches of Admetus in threnos).

3. Hipp. 1370-1378 (of Hippolytus), And. 501-544 (515$522=537-544$ of Menelaus), Hec. 154-215 (of Hecuba and Polyxena), Ion 859-922 (monologue of Creusa), Rh. 527-564 (538-545 = 557-564).

Euripides uses the anapaest more than Sophocles does, and he employs it at times in a more formal manner. This is especially seen in the conventional endings which are repeated at the conclusion of several plays. The use of such general schemes in eight out of nineteen plays seems to show a loss of spontaneity, but it is possible that Euripides did not write them. The poet uses freely lyric anapaests, often modified and admitting many substitutions.

In the anapaests employed at the entrance of characters, Euripides follows the tradition of Aeschylus. The dramatic power of this use can be seen in Ag. 782-809 and P. V. 561-565, examples of a speech by the chorus and of one by the entering actor. Sophocles treats such anapaests in a colorless way. ${ }^{1}$ Ant. 376-383 is the only passage in which the chorus addresses the person entering. Although Euripides uses the metre here at times in a manner similar to that of Sophocles, he often employs it as in $E l$. 988-997, where the greeting of the queen is on a splendid scale, and in Tro. 568-576, where there is a striking description of Andromache on her way to the ship. In several passages, ${ }^{2}$ the chorus addresses the actor entering, and in others, ${ }^{3}$ it addresses some character or characters already on the stage. I. A. 590-606 is similar in type to Pers. 150-154, although the latter case seems more like an actual address.

1 Cf. Ant. 626-630.

2 And. 494-500, Tro. 568-576, El. 988-997, Or. 348-355, Rh. 379-387.

'Tro. 1118-1122, 1251-1259, I. T. 456-466, Rh. 882-889. 
Finally in Hyps. iv, 5(3)10-14, the chorus appeals to Zeus of Nemea for information concerning the approaching stranger. Even where there is no address of one of the actors, Euripides is apt to give more information and show more variety in form than Sophocles. A comparison of And. 1226-1230 and Ant. 526-530 shows this. Aeschylus avoids formalism on the whole, even when the chorus delivers the passage as in $A g .782-809$.

It is especially in the anapaests at the entrance of characters that Euripides follows the usage of Aeschylus, and it is here that he differs most markedly from Sophocles. Semimelic passages the two later poets treat in rather similar fashion, but Euripides develops and uses melic anapaests more freely. Finally at the end of plays Euripides carries on the change commenced in the dramas of Sophocles and employs more formal schemes than either Sophocles or Aeschylus. The latter, in fact, avoids any such moralizings at the conclusion of a piece.

Euripides uses the anapaests most frequently in the earlier plays, but toward the end of the third period, he largely discards them. The metrical variety thus lost he regains through the revival of the trochaic tetrameter. 


\section{CHAPTER VI}

THE TROCHAIC TETRAMETER

UNLIKE the anapaest, the trochaic tetrameter passed almost out of use in the later stages of Aeschylus' career, and later, after a long period of neglect, it reappeared. Euripides revived it in the second period of his work and used it ever more freely. Sophocles never cared for it, or at least he employed it very sparingly.

Kanz ${ }^{1}$ thinks that Euripides used this metre for two purposes: (1) to give a dignified account of serious matters; (2) in altercations which the lively movement of the metre suited. Prof. Verrall ${ }^{2}$ says that Bacch. 604-641 (trochaic lines) shows the influence of comedy and indicates that we are not to treat Dionysus seriously. Kanz, however, places this same passage in his first class.

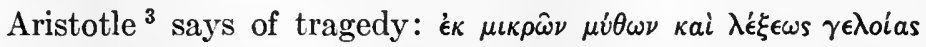

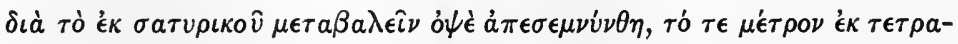

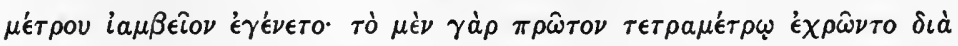

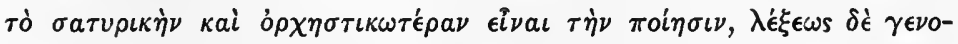

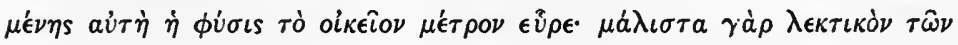

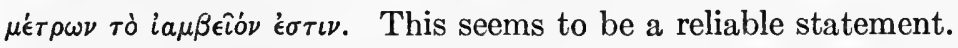
Whatever the origin of tragedy, the trochaic was probably the metre first used, and it seems certain that tragedy was originally of religious origin and that deities appeared on the stage.

Although the trochaic seems more rapid than the iambic and is less often used for long speeches, still in the Iphigenia in Aulide there are trochaic speeches of 42 lines $^{4}$ and 24 lines, ${ }^{5}$

1 De tetrametro trochaico, p. 25.

3 Poetics, p. 1449 a 19 ff.

2 Bacchants of Euripides, p. 76.

$4334-375 . \quad$ s $378-401$. 
respectively. The poets, then, could use long trochaic speeches. Conversely, in the Ion, in which this metre is used considerably, there are an iambic stichomythy of 105 lines $^{1}$ and another of 91 lines. $^{2}$ Trochaics, then, are not always used in scenes with rapid movement.

The trochaics in the Persae, the earliest play in which they occur, are arranged in an interesting manner. The first passage in which they are found ${ }^{3}$ contains also a long iambic speech by Atossa. ${ }^{4}$ This might seem to indicate that trochaics were not used for long speeches. It is more significant, however, that this iambic section describes the dream and the portents seen by the queen. When she speaks with the chorus as a mortal, she uses trochaies, but when she reveals the will of the gods, she employs iambics.

The second scene ${ }^{5}$ can be explained in the same way. In 681-693, Darius, a prince among the dead, appears in response to the rites of Atossa and the chorus. He uses iambics. The chorus, filled with awe, says:

$$
\begin{aligned}
& \sigma \dot{\epsilon} \beta 0 \mu a \iota \mu \dot{\epsilon} \nu \pi \rho \sigma \sigma \delta \dot{\epsilon} \sigma \theta a \iota \text {, }
\end{aligned}
$$

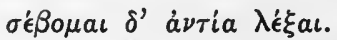

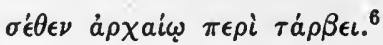

He turns to the chorus and in trochaics asks it to speak $\tau \dot{\eta} \nu$ ${ }^{\prime} \mu \dot{\eta} \nu$ ai $\delta \hat{\omega} \mu \epsilon \theta \epsilon i{ }^{7}$ He then appeals to the queen and learns from her of the disastrous expedition of Xerxes. ${ }^{8}$ During this trochaic passage, the ghost is learning about the conditions of his realm and seemingly knows nothing of what has happened since his death. At 759, he changes back to iambics, repeats the history of the Persian kings, and, foretelling the future, warns against another expedition to Greece and departs. Darius uses trochaics while he is seeking information, i.e. while he is a dead mortal. When he assumes the rôle of divine prophet and
$1264-368$.
3 155-248.
s 681-851.
7699.
2 938-1028.
176-214.
- $694-696$.
8 703-758. 
preacher, -i.e., is the hero or god, - he uses iambics. At the end of the scene ${ }^{1}$ Atossa and the chorus also speak in iambics. This is due to the fact that Darius is the protagonist and to the poet's reluctance to change the metre for the few lines. We do not find anywhere a conversation in which both iambics and trochaics are simultaneously used.

In the Agamemnon, the trochaic lines 1344, 1346, 1347, may be regarded as expressing strong feeling or as revealing something which takes place off the stage. Probably they are used to emphasize 1343, 1345, the cries of the stricken king. Later, when the chorus says,

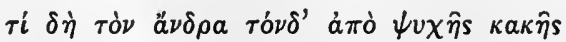

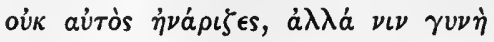

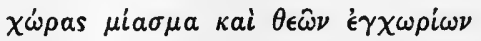

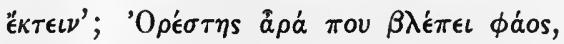

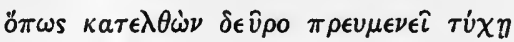

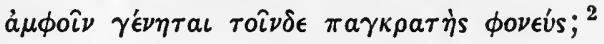

Aegisthus interrupts with the words:

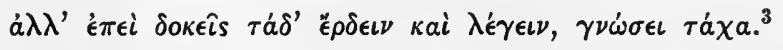

The mention of the return of Orestes seems to cause the change; yet the meeting of mother and son, ${ }^{4}$ in a sense the climax of the trilogy, contains an iambic stichomythy. In the Agamemnon, Wecklein ${ }^{5}$ alters the order of lines and emends unnecessarily. If we should accept his changes, we should be obliged to consider the metre as marking in a scene of excitement the conclusion of one play of a trilogy. It is possible, however, that the prediction of the exile's return may influence the verse here, although this must not be too much emphasized.
$1843-851$.
4. Ch. 892-930.
$21643-1648$.
- Äschylos' Orestie, p. 159, note on $1643 \mathrm{ff}$.
31649. 
Probably in Oedipus Rex 1515-1530, trochaics are used merely as the ending of the play. These lines follow a scene which contains prayers and predictions, but we do not need to follow Prof. Murray's hint ${ }^{1}$ and see in the departure of Oedipus for Cithaeron a faded theophany.

In Oedipus Coloneus 887-890 (trochaic lines), Theseus enters in haste, but it is interesting to note that he leaves the altar of Poseidon to rescue Oedipus. Once again there is at least a reference to a god in the trochaic passage.

Philoctetes 1402-1407 is an interesting case. After Philoctetes says:

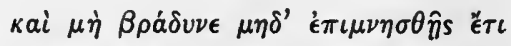

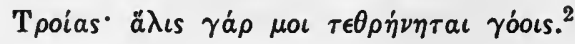

Neoptolemus answers in trochaics:

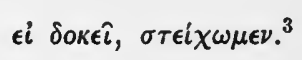

Just as the two start, the anapaests of Heracles are heard and Philoctetes is told to go to Troy. Heracles gives his commands in iambics and then the final anapaests begin. The use of trochaics before the appearance of the gods obeys the rule which we observed in the Persae.

Except for the Rhesus, the earliest case of trochaics in the plays of Euripides is Hercules Furens 855-873, near the opening of the second part of the drama. In 822-854, Iris and Lyssa discuss the orders of Hera, and Lyssa refuses to obey. Iris says:

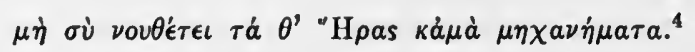

Of course she is overshadowed by her mistress, and the use of trochaics shows this. Lyssa submits. Just as Darius in the Persae turned to iambies when he uttered his prophecy, so these goddesses commence trochaics when they obey the commands of Hera, and the change of metre makes clear their subordination.

1 Ritual Forms, p. 358.

2 1400-1401.
3 1402.

- 855 . 
In the Ion, the same rule is observed. In the trochaic passage 510-565, Ion inquires about Xuthus, and the section describes the oracle and its fulfilment. As soon as this is ended, the iambics, the normal measure of dialogue, begin again. In a scene of wild excitement, ${ }^{1}$ after the failure of her plot, Creusa flees to the altar. It is noteworthy that the trochaics begin here again when the characters come into contact with the divine. Ion despite his excitement uses iambics. Finally at 1553 Athena appears and delivers a long speech in iambics. Properly, at the close, Ion resumes trochaics ${ }^{2}$ and the play ends with them. The words of Athena in these lines are of slight importance. She has delivered her message and the interest centres on the mortals. Just as in Pers. $787 \mathrm{ff}$. the chorus used iambics after Darius had finished, here Athena speaks in trochaics to prevent awkward changes of the metre.

Troades $444-461$ is a similar case. In $427-443$, Cassandra predicts the fate of Odysseus. Suddenly she changes and says:

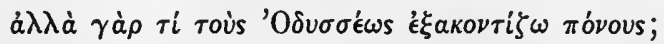

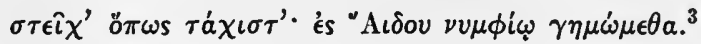

She foretells her own death and Agamemnon's. The keynote of the passage is "Farewell." The prophetess changes from the inspired seer to the wretched captive, and so the metre marks the descent from divine to human.

Kanz ${ }^{4}$ divides Iphigenia in Tauris 1203-1233, assigning 1203-1221 to the second division and $1222-1233$ to the first as a solemn proclamation. This is unnecessary, as the underlying thought is the same. The orders are given first to Thoas and then to all, so that no real division exists. In these lines, Iphigenia applies the divine commands to mortals, after the iambics $^{5}$ have revealed the pretended will of the goddess.

1 1250-1260. $1606 \mathrm{ff}$.
3 444-445.

4 Op. cit., p. 25.
5 1153-1202. 
This passage then is regular and the choice of metres is another evidence of the cleverness of Iphigenia.

Helena 1621-1641 is a scene of great excitement, for Theoclymenus is planning vengeance on his sister, because she has allowed Helen to escape. At the close of this section, the Dioscuri appear and in iambics forbid the king to punish Theonoe or to pursue the fugitives. After they have finished, the king assents briefly in iambics, but this apparent irregularity is due to the same reason as in the Persae and the Ion.

The Phoenissae shows a wider use of this metre. In 588-637, the trochaics are employed without reference to divinity, but they give a very animated movement to the quarrel of the two brothers. 1308-1309 and 1335-1339 have a somewhat emotional character. Finally 1758-1763 (deleted by Wilamowitz) seem to point definitely to the ending of the Oedipus Rex. In this play, then, for the first time in Euripides, the metre cannot be connected with divinity.

In the Orestes, the return of Pylades and the leaving of the friends for the assembly ${ }^{1}$ are described in the trochaic metre. The motive is approximately that of $A g .1649 \mathrm{ff}$., but trochaics are probably used for the sake of the rapid movement. The same is perhaps true also of 1506-1536, the meeting of Orestes and the Phrygian, and 1549-1553, the announcement of the coming of Menelaus.

In Bacchae 604-641, Prof. Verrall uses the metre as an argument for his view of the plot. This is not a strong argument. Nowhere have we found a god as god using the trochaic metre. The clue is given in $622-624$ :

\section{$\dot{\epsilon} \nu \delta \dot{\epsilon} \tau \hat{\varphi} \delta \epsilon \tau \hat{\varphi} \chi \propto \rho \delta \nu \omega$}

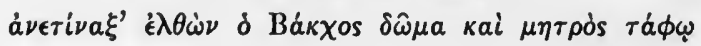
$\pi \hat{v} \rho \dot{a} \nu \hat{\eta} \psi \epsilon$.

Dionysus is pretending to be one of his own followers. ${ }^{2}$ As Darius, when speaking as the dead king, used trochaics, so here
$1729-806$.
${ }^{2}$ Cf. 494, 498, 517. 
Dionysus, posing as a mortal, speaks in the same metre. This emphasizes in a very skilful manner the disguise of the god.

In the Iphigenia in Aulide, the scene between the two brothers is in trochaics. ${ }^{1}$ In this, as in 855-916, the poet chose this metre for no apparent reason. Still, in the second passage, it is interesting to note that the queen appeals to Achilles, the son of the goddess Thetis, in terms applicable to a god. ${ }^{2}$ Yet we must not insist too strongly upon the divine parentage of Achilles as responsible for the use of the trochaics here. We might find some connection perhaps in 1338-1401, where Iphigenia consents to die for the Greeks. It is more likely, however, that Euripides used this metre for important scenes without the usual limitations.

Rhesus 683-684, 686-691 are trochaic. They occur in the fight between the Trojans and the Greek chiefs, but we must remember that Odysseus and Diomedes are acting at the instigation and under the direction of Athena.

As we do not know the context in which the trochaic lines preserved among the fragments were situated, they do not concern us here.

It is difficult to agree with $\mathrm{Kanz}^{3}$ that Sophocles used the trochaic as a substitute for the anapaestic metre. No doubt in the Agamemnon, Oedipus Rex, and Ion, it does seem to encroach upon the field of the anapaest, but the use of the latter metre in a situation like $O$. C. 887-890 would not be in harmony with the usual Sophoclean practice. Similarly, in Phil. $1402 \mathrm{ff}$., we should not expect anapaests when the entrance of Heracles is announced in the same metre. There may be some encroachment in Phoen. 1308-1309 and Or. $1549 \mathrm{ff}$., but the

$1317-375,378-401$.

2 Cf. $900-901$,

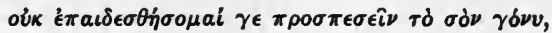
$\theta \nu \eta \tau$ òs '̇́ $\theta \epsilon a ̂ s ~ \gamma \epsilon \gamma \hat{\omega} \tau a$,

and also $903,911$.

Op. cit., p. 23. 
hortatory character of these passages would render them unsuited for conventional anapaestic treatment.

We may then trust Aristotle in his statements as to the original use of this metre in tragedy. It was early given up, but it retained its position longest in marking the separation of human and divine and at the end of plays. In these places it reappeared first, and only in the later plays of Euripides is it used in important scenes without such cause.

Its use in tragedy is irregular, for the iambic trimeter had obtained such a hold as the normal metre of dialogue that it could not be displaced sufficiently for the poets to use the trochaic tetrameter consistently. Euripides, however, employed it very freely and seemingly cared for it, perhaps because of his love of archaism. 


\section{CHAPTER VII}

DESCRIPTION

The plays of Aeschylus and Euripides contain long descriptive passages which often materially delay the action of the drama. In this discussion, I shall consider neither most of the speeches of the messengers nor such sections as have mainly political importance, e.g., Eur., Supp. 399-462, but shall confine myself to those passages which contain definite pieces of description and narration.

Critics differ in their judgment of the long geographical descriptions in the dramas of Aeschylus. Prof. Post ${ }^{1}$ condemns them. Mr. Sheppard is less severe and thinks that in the Supplices the description of the kingdom of Pelasgus is very dramatic and balances the invocation of Zeus. ${ }^{2}$

Among such passages are: Supp. 249-273, the description of the kingdom of Pelasgus, and 277-290, the names of the races to which he compares the daughters of Danaus; $P . V$. 640-686, Io's account of her wanderings, and 700-741, 786-876, Prometheus' recital of other portions of her travels and of her future toils. (This does not agree with the choral passage Supp. 538-564.) The easy transition from description to narration is seen in $P . V .846-876$, where the Titan mentions the fate of Io's descendants, and in $A g .281-316$, where the queen describes the coming of the fire-signals from Troy to Argos. In Pers. 480-514 we learn about the retreat of Xerxes, and in the ode 864-896 about the conquests of Darius. Among

1 The Dramatic Art of Aeschylus, Harvard Studies, Vol. XVI, p. 58.

2 The First Scene of the Suppliants of Aeschylus, Classical Quarterly, Vol. V, p. 228. 
the fragments, we may mention 30-32 from the Glaucus Pontius and those from the Prometheus Solutus. Frag. 199 certainly, and 195-198 probably, describe the journey of Heracles to the home of Geryon. Frag. 190-192 from the parodos tell of the route of the Titans on their way to visit Prometheus.

Such geography is often united with other kinds of description. In Supp. 291-324, Pelasgus and the maidens discuss genealogy. Eum. 1-29 contain a list of the deities who formerly owned Delphi or were worshipped there. We may mention here also the history of the kings of Persia $^{1}$ and the lists of names in the same play. ${ }^{2}$ Among long passages more frankly narrative are $P . V .199-243$ and 436-506, the account of the career of Prometheus and of the benefits which he had conferred on mortals. Perhaps we may mention here Sept. 369-719, the description of the seven chiefs who lead the attack on Thebes.

Some choral odes have the same characteristics. Such are: Supp. 538-564, the wanderings of Io; Pers. 548-597, the expedition of Xerxes, and 852-908, the reign and conquests of Darius; Sept. 720-791, the history of the Labdacidae; $P . V$. $399-435$, the universality of the lament for Prometheus; $A g$. 40-257, the history of the Trojan war and the sacrifice of Iphigenia; and $C h .22-41$, the description of the dream of Clytaemestra and its effects.

We see then that if Aeschylus tells a story in dialogue or ode, it is usually connected with the plot of the play. $\mathrm{He}$ is fond of long iambic descriptions of geography, but he skilfully combines in these both narrative and geography.

Sophocles used such description relatively little. Such passages, as Ant. 909-912 and O.C. 337-345, which are thought to show the influence of Herodotus, are hardly to be compared with the descriptions of Aeschylus. In citing from the Triptolemus (frag. 541), Dionysius of Halicarnassus (Antiq. I, 12), states that in this play Demeter predieted the wanderings of
1 Pers. 759-786.
2 1-64, 302-330, 955-1001. 
Triptolemus in considerable detail; but this drama seems exceptional. We do not know the extent of the description of the river Inachus seen in frag. 249 (Inachus). In the Trachiniae are brief descriptions of the marriage of Deianeira ${ }^{1}$ and of some of the labors of Heracles. ${ }^{2}$ There is little detailed narration in Ant. 100-154 and Aj. 134-171, and in Ant.806-832, 944987 (the comparison of Antigone with other famous sufferers).

Euripides follows Aeschylus rather than Sophocles. Prof. Murray $^{3}$ remarks on Euripides' indifference to geography. This seems true only if we take as measure for comparison the grander passages of Aeschylus, but even there narration and geography tended to fuse.

Among passages where we find such description, we may cite Cycl. 290-298, a list of temples of Poseidon, and Hec. 444-474 and Tro. 187-229, two choral odes in which the probable destination of the captives is discussed. In the prologues, as Bacch. 13-22, the travelling of Dionysus, frag. 228 (Archelaus), the wandering of Danaus, and frag. 819 (Phrixus), the story of Cadmus, we find some well-marked cases of this usage. Frag. 383 (Theseus) describes Hades, but as we know it only from the parody in Aristoph., Ran. $470 \mathrm{ff}$., it is of no value for our purposes.

I shall pass over the use of genealogy in the prologues, of which frag. 14 (Aeolus) is a very good instance. In Her. 207212, the relationship of Theseus and Heracles, and in $I$. A. 695-713, the ancestry of Achilles, are discussed much as the lineage of the daughters of Danaus in Aesch., Supp. 291-324.

Euripides treats classes of subjects which Aeschylus does not describe, as the tent of Xuthus at Delphi. ${ }^{4}$ In Supp. 857-917, Adrastus delivers a funeral oration praising the various dead chieftains. Although we have not considered the speeches of the messengers, Phoen. 1090-1199 should be mentioned be-

$1-48$.

2 1090-1102.
3 History of Ancient Greek Literature, p. 228.

4 Ion, 1141-1166. 
cause of its similarity to the account of the leaders in the Septem of Aeschylus.

It is in the choral parts that Euripides most uses both description and narration. The parodos of the Iphigenia in Aulide 1 deseribes the Greek camp at Aulis, and in magnitude it is worthy of comparison with some of the work of Aeschylus. Similar but shorter are the parodoi of the Ion ${ }^{2}$ with its deseription of the temple of Apollo at Delphi and that of the $H e c u b a^{3}$ with details eoneerning the couneil at which it was decided to sacrifice Polyxena. In I. T. 203-235 and Hel. 191211, a character reviews the fortunes of his relatives.

Euripides also has a number of choral songs of varying length which are frankly narrative poems at times loosely connected with the plot. Such are: $H . F .348-441$, the description of the labors of Heracles; El. 432-486, the praise of Achilles' might and the picture of his shield; 699-746, the story of the quarrel of Atreus and Thyestes over the golden lamb; I. T. 1234-1283, the history of the conquest of Delphi by Apollo, and his dispossession of $\mathrm{Ge}$, the former owner of the shrine; Phoen. 638675, the tale of Cadmus and the dragon; 1019-1066, a summary of Theban history from the meeting of Oedipus and the Sphinx; and $I$. A. 1036-1079, an account of the wedding of Peleus and Thetis. Such songs occur most frequently in the later periods of Euripides' career.

In the use of description by the various poets, we find different tendencies. Aeschylus is most interested in geography, and his narrative odes are closely connected with the theme of his plays. Sophocles neglects formal description. Euripides, in spite of his smaller interest in geography, on the whole, follows Aeschylean usage. In later life he inserts into his plays narrative odes which are very loosely connected with the plots of his dramas - herein also reviving and continuing the traditions of Aeschylus rather than those of Sophoeles.
1 164-302.
${ }^{2}$ 184-218.
3 98-153. 


\section{CHAPTER VIII}

\section{DREAMS}

IN their treatment of dreams, Aeschylus and Euripides again agree with each other and differ from Sophocles. The references fall into two groups: (1) those which are meant to be taken seriously and are of importance to the play; (2) those which emphasize the unsubstantial character of these apparitions, often mere metaphorical passages hardly worthy of mention.

The dream of Atossa in Pers. 176-200 is very important. She sees in her sleep Xerxes trying to yoke to his chariot two women, one a Greek, the other a barbarian. The former is not submissive and breaks loose, and the king falls from the chariot. This dream is a portent and is confirmed by the sight of the hawk pursuing the eagle to the hearth of Phoebus. ${ }^{1}$

In P.V. $645 \mathrm{ff}$., dreams warn Io to leave home and become the beloved of Zeus. She tells her father Inachus,

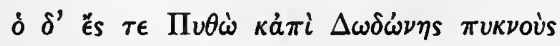

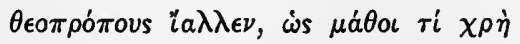

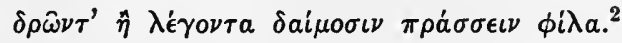

When a clear answer is received,

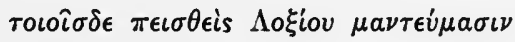

$$
\begin{aligned}
& \dot{\epsilon} \xi \dot{\eta} \lambda \alpha \sigma^{\prime} \boldsymbol{\epsilon}^{\nu} \mu \epsilon^{3}
\end{aligned}
$$

Loxias then is the interpreter of dreams, although Prometheus says that he himself has taught this art to mortals. ${ }^{4}$ The sender is not definitely stated.
1 205-210.
2 658-660.
3 669-670.
4 485-487. 
In the Choephori, Clytaemestra dreams that she bears and nurses a serpent, which later stings her breast. Terrified by this vision, she sends libations to Agamemnon's tomb. ${ }^{1}$ On hearing the dream, Orestes accepts the omen,

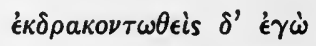

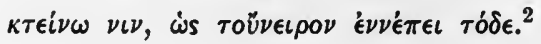

The queen applies it:

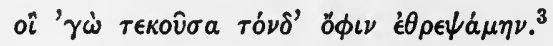

and Orestes answers:

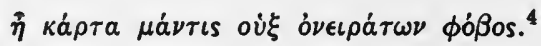

In the Eumenides, the ghost of Clytaemestra rouses and reproaches the sleeping Furies, because they are not pursuing Orestes. When awakened, one of the goddesses says:

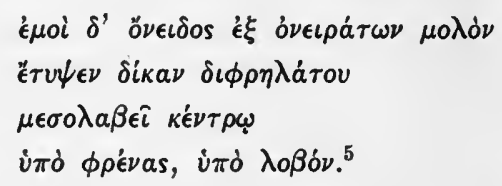

Similarly, in $A g .1218$, Cassandra sees the ghosts of the murdered children of Thyestes, ó $\nu \epsilon i \rho \omega \nu \pi \rho \circ \sigma \phi \epsilon \rho \epsilon i s ~ \mu о \rho \phi \dot{\omega} \mu a \sigma \iota$.

Among references of the second class, we may mention the following. The daughters of Danaus call the outrage of the

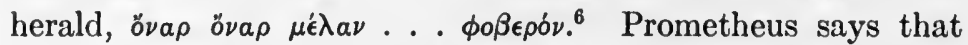

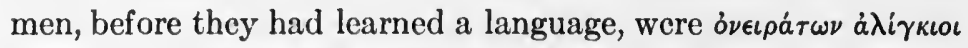

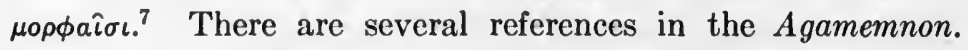
In 82 , because of his weakness an old man is called ö $\nu a \rho \dot{\eta} \mu \epsilon-$ póфavтov. In 275 , the queen, denying that she has heard of the fall of Troy through dreams, says:

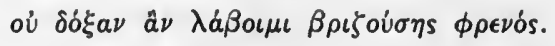
$132 \mathrm{ff}$.
3928.
- $155 \mathrm{ff}$.
7 P. V. 448-449.
${ }^{2} 549-550$.
4929.
- Supp. 888 ff. 


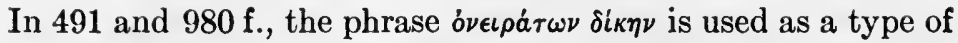
something that is easy to efface.

Aeschylus often considers dreams as portents. He does not name the sender, but he shows them as obedient to the will of Zeus. Apollo is the best interpreter and sees that they are obeyed, as mortals can also interpret. The poet also uses dreams as a type of the unsubstantial. Dreams and the spirits of the dead, especially of the murdered, are closely connected.

In the extant plays of Sophocles, there is but one important dream, and that one is probably due to the influence of Aeschylus. In Electra $417 \mathrm{ff}$., Chrysothemis tells how her mother dreamed that the sceptre of Agamemnon took root and grew till it overshadowed all Mycenae and how in consequence she sent libations to her husband's tomb. This dream is often mentioned, ${ }^{1}$ but it is not used as an omen to encourage Orestes as is the one in the Choephori. The unreal class is represented in O.R. 981 and frag. 62 (Acrisius).

The Hecuba of Euripides contains an important passage on this subject. The ghost of Polydorus concludes his speech with

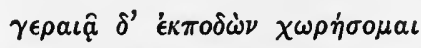

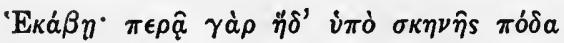

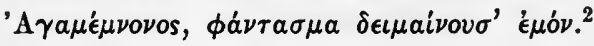

Hecuba then says:

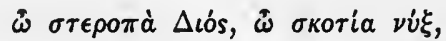

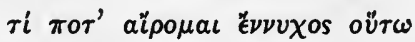

$\delta \epsilon i \mu \alpha \sigma \iota, \phi a ́ \sigma \mu \alpha \sigma \iota \nu ; \tilde{\omega} \pi \dot{r} r \nu \iota \mathbf{X} \theta \dot{\omega} \nu$,

$\mu \epsilon \lambda a \nu 0 \pi \tau \epsilon \rho \dot{\gamma} \gamma \omega \nu \mu \hat{\eta} \tau \epsilon \rho$ ó $\nu \epsilon i \rho \omega \nu$,

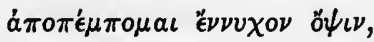

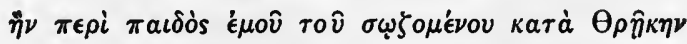

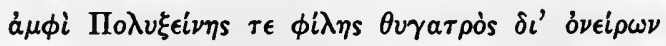

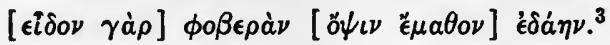

${ }^{1}$ Cf. 480 f., 501, 644 f., 1390.

${ }^{2} 52-54$

$368 \mathrm{ff}$. 
She seeks an interpreter:

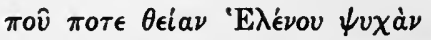

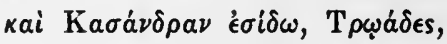

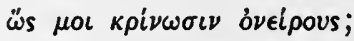

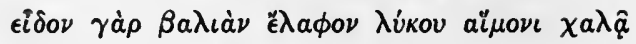

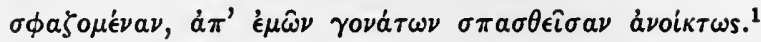

She fears for her daughter's life, because the ghost of Achilles has recently appeared and demanded that one of the Trojan maidens be sacrificed to him, and she has not yet learned whether the chieftains have decided to obey this savage command. We should note that here the source of dreams is $\mathrm{X} \theta \dot{\omega} \nu$ and not some associate of Zeus or Apollo. Later ${ }^{2}$ the queen laments that she did not need an interpreter, for she herself had guessed too well the sad truth.

The dream in the Iphigenia in Tauris is also important. Iphigenia dreams that she has consecrated to Artemis the one column of her ancestral palace which had withstood a severe earthquake. $^{3}$ She concludes that Orestes is dead $^{4}$ and tells this to the chorus. ${ }^{5}$ When she learns that her brother is still alive, she says:

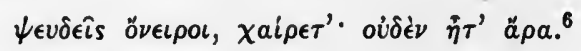

Orestes answers:

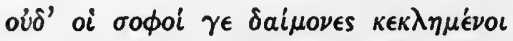

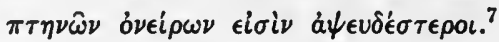

The choral passage 1234-1283 explains why the dream is misleading. Ge had been dispossessed by Apollo, and in revenge sent dreams to weaken the intruder, until Zeus interfered to help his son and restore him to honor at Delphi. Although the poet views this strife as past, he shows that dreams are not from Apollo but from the enemy of the god, the dispossessed Ge.
$187 \mathrm{ff}$.
$32 \mathrm{ff}$.
$5143 \mathrm{ff}$.
7 570-571.
$2702 \mathrm{ff}$.
1 56 ff.
- 569. 
Among minor passages and those of the second class are the following. In Or. 616 f., Tyndareus attacks Electra because by telling dreams about Agamemnon she has stirred up hatred against her mother. In $C y c l$. 8, Silenus asks if his part in the battle of the gods and giants was but a dream. In Alc. $354 \mathrm{f}$., Admetus declares that his dead wife will comfort him by appearing in dreams, an idea analogous to that of frag. 107 (Alope). In $H . F .517 \mathrm{ff}$., Heracles appears like a dream to his family. Like Aeschylus, Euripides refers to old men as dreams or shadows of dreams in H.F. 112, Phoen. 1722, and frag. 25 (Aeolus). In Phoen. 1545, Oedipus wishes to know if he has been summoned because of a dream. To the charioteer, the attack on Rhesus seemed a dream. ${ }^{1}$ Frag. 533 (Meleager) says that, even in dreams, one does not care for the darkness of Hades.

Like Aeschylus, Euripides both emphasizes the unreality of dreams and makes them important in the economy of his plots. Aeschylus regards them as under the control of Zeus or Apollo, as far as they are substantial. Euripides, who in this shows stronger traces of archaism or even popular theology, connects them quite definitely with Ge, $\mathrm{X} \theta \dot{\omega} \nu$, the goddess of Earth, one of the older deities, independent of and even hostile to Zeus and Apollo. Yet the prophets of Apollo, as Cassandra, interpret. Since Sophocles rarely used dreams in his dramas, it is Euripides again who evidently continued the tradition of Aeschylus.

1 Rh. 782. 


\section{CHAPTER IX}

\section{THE RELIGION OF EURIPIDES}

Perhaps it is in the religious sphere that we find some of the most interesting examples of Euripides' archaism. These may be due partly to dramatic and technical considerations, but they are also partially caused by the attitude of the poet towards religion itself. In many ways doubtless the poet was an innovator in this field; yet it is dangerous to generalize in regard to his belief. We must never forget that Euripides was writing on religious themes for a religious festival.

A very frequent cause of misconception of the poet's attitude is a tendency to overemphasize the unity of Greek religion. So Prof. Verrall ${ }^{1}$ writes:

"To every human being, that power, which he thinks capable of dealing in the last resort with human life, is God. On his conception of that power depends, directly or indirectly, all that he can think. In the days of Euripides the defenders of old religion maintained with regard to this question exactly what is assumed in the prologue [of the Alcestis], that this power resided in certain beings, who had many organs of communication with man, but one organ of incomparable importance, the oracle of the Pythian Apollo: and upon this foundation reposed a vast structure of social, civil, and national usage just then beginning perceptibly to totter."

From this point of view, it is easy for him to conclude that Euripides did not believe in the gods. Yet it is admitted that there was no official creed and that the gods were of different origins. Euripides is called a rationalist because he criticized the gods, and to prove the eharge, his views of Zeus and Apollo

1 Euripides the Rationalist, p. 114. 
are cited. These are not the whole pantheon, and some would consider them late arrivals in Greece and maintain that their worship was fostered by the tyrants in order to reduce the power of the nobles who supported the local cults. ${ }^{1}$ To understand Euripides' views, one should study separately the treatment of each god, always remembering that Euripides was bound to respect the externals of religion because of the position of Greek tragedy as a religious ceremony. Then we might not agree with the cynical interpretation of $\mathrm{Hel} .1301 \mathrm{ff}$. set forth by Mr. W. Scott: ${ }^{2}$ "The gods kill us for their sport and we persuade ourselves that we can secure ourselves against the malignity of fate - by beating a tambourine." The following are offered as examples of the way in which Euripides' attitude toward different gods varies, and to show how we may detect a noticeable archaistic tendency in his treatment of them.

\section{Dionysus}

Dionysus and the Bacchae form a natural centre around which the discussion of Euripides' religion revolves. Is this play a recantation or an attack on the god? Whichever is true, the spirit of this drama seems different from that of any of the earlier plays.

Most scholars are agreed that the connection of Dionysus and tragedy was very close and, if not original, yet of long standing. A Pentheus of Thespis is mentioned, although Nauck ${ }^{3}$ declares that the titles and fragments of the plays of Thespis are spurious. We know only the title and one line of the Orpheus of Aristias, probably a drama on a Dionysiac subject, but nothing of the treatment.

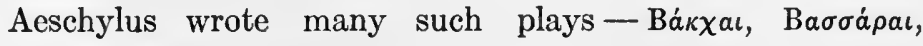

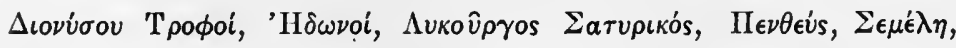

1 Sheppard, Greek Tragedy, p. 3.

2 The Mountain-Mother Ode in the Helena of Euripides, Classical Quarterly, Vol. III, p. 170.

${ }^{3}$ Frag. ${ }^{2}$, p. 832. 
Neaviorol. In contrast to this list, the references to Dionysus in the extant plays are few and mostly unimportant. Such are:

Sept. 497-499, ('I

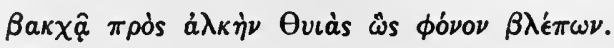

835-836 є̈

Oviàs $\ddot{\omega}$.

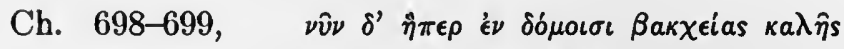

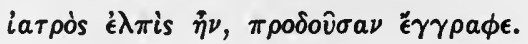

In Eum. 24-26, we have a definite mention of the worship of Bromios at Delphi. In frag. 5 (Aegyptii) and 228 (Sisyphus) the name Zarpeís is found. In frag. 341, we have:

and in frag. 355 ,

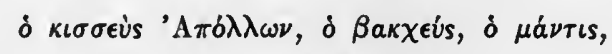

$$
\begin{aligned}
& \text {.. } \mu l \xi o ß o ́ a \nu ~ \pi \rho e ́ \pi \epsilon l
\end{aligned}
$$

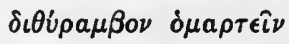

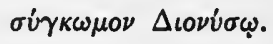

To Aeschylus, Dionysus seems to have been a god of revel and ecstasy, of untamed emotions; yet the poet, because of his especial devotion to Zeus, allows Dionysus to take a subordinate place in plays on non-Dionysiac themes.

Sophocles apparently wrote no serious Dionysiac drama, although he mentions the god more frequently than does Aeschylus. Among the instances we may cite Ant. 136, where the word $\beta a \kappa \chi \epsilon i \omega \nu$ is used to describe the manner in which Capaneus attacked Thebes. Some of the passages in which the god is named in connection with Thebes are Ant. $153 \mathrm{f},{ }^{1} 1121 \mathrm{ff}$., $T r$. $510 \mathrm{ff}, O . R .209 \mathrm{ff}$. In Ant. 957, his punishment of Lycurgus, son of Dryas, is mentioned. He is connected with the grape in Tr. 704 and frag. 234 (Thyestes). In O.R. 1105, he is regarded as a possible father of Oedipus. In $O . C .679$, he is at Colonus, and in frag. 874, he loves Nysa. Finally in frag. 607 (Tyro),

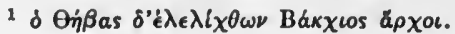




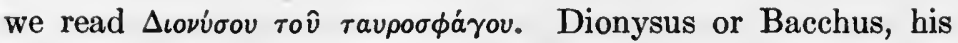
more common name, is especially associated with Thebes.

To appreciate the neglect of Dionysus, even in his own domain, we must consult the Ichneutae. In 127, we find the phrase,

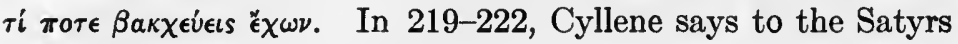
concerning their master Silenus:

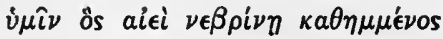

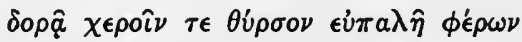

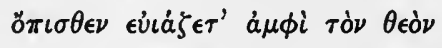

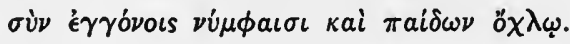

Dionysus is not mentioned by name, and the poet does not emphasize the connection between the god and the Satyrs.

The atmosphere of the Cyclops of Euripides is very different. The opening words, $\hat{\omega}$ B $\rho{ }^{\prime} \mu \iota \epsilon$, give the keynote. Silenus and his crew, while on their way to rescue Dionysus from the pirates who have captured him, have been seized by the Cyclops. The god is mentioned frequently and always respectfully. $\mathrm{He}$ is pre-eminently the god of wine. ${ }^{1}$ Some passages, as 519-520,

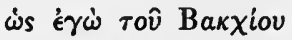

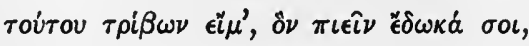

might suggest that the god and wine are identified, but others,

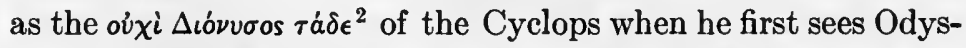
seus, and the prologue, seem to show that we are not to consider Dionysus merely as the personification of the vine, although this conception is sometimes present. In this connection, 521522 are significant, -

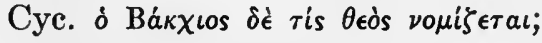

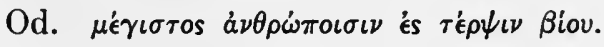

We must remember, however, that Odysseus is praising wine to deceive the Cyclops. The only reproach of the god is in 527:

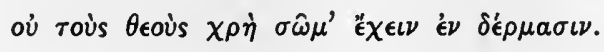

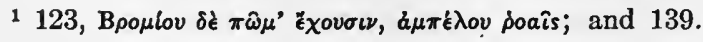

2204. 
When we compare this with the blasphemous words of the Cyclops commencing,

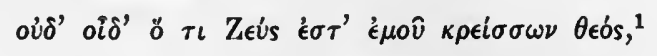

and with the attitude of Odysseus towards Zeus, ${ }^{2}$ we see how well Euripides treats Dionysus. Important also are 63-67 and 205, where the cymbals and rattles, often associated with Cybele, are mentioned.

In the Hippolytus, we hear more of Dionysus. Phaedra

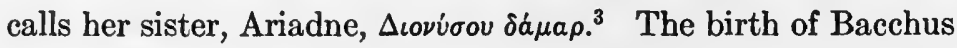
is hailed as one of the works of Cypris." Finally Theseus addresses his son:

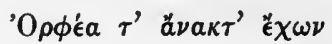

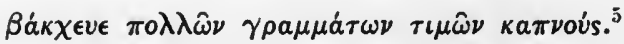

In this passage, it is difficult to determine whether or not the poet is clearly thinking of the connection between Bacchus and

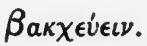

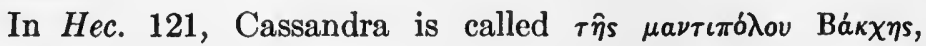
and a similar phrase is used of her in 676-677, Tro. 408, 500, and elsewhere. In Hec. 686-687, Hecuba expresses her woes in

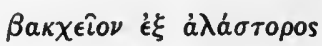

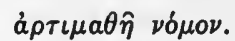

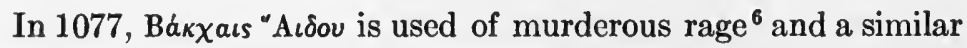
phrase is applied to the maddened Heracles in $H . F .1119$. Finally in Hec. 1267, the oracle which Polymestor tells to Hecuba

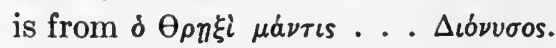

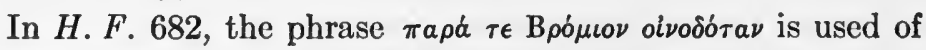
a feast. On hearing the cries of Amphitryon, the chorus says,

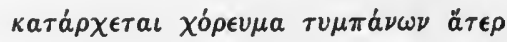

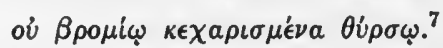

Here again is a reference to the ritual instruments of Cybele.
1321.
${ }^{3} 339$.
s 953-954.
7 891-892.
? 353-355.
4 559-560.
- Heberden, Hecuba, p. 120. 
In Ion 216-218, the chorus mentions Bacchus' participation in the battle of the gods and giants as a subject represented among the temple sculptures. Dionysiac feasts at Delphi are mentioned several times. ${ }^{1}$ In 1232 , the attempted murder of

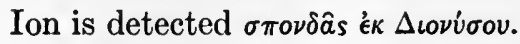

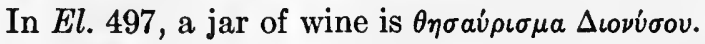

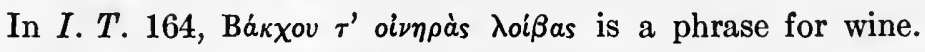
In 1243-1244, the revellings of Dionysus at Delphi are again mentioned.

In Hel. 543-544, Helen says, on seeing Menelaus:

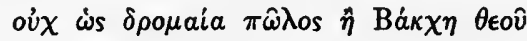
$\tau a \dot{\phi} \omega \xi \nu \nu \alpha \dot{\psi} \omega \kappa \hat{\omega} \lambda o \nu$;

There is a union of Dionysus and the Mother in $1358 \mathrm{ff}$.:

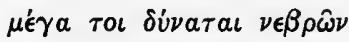

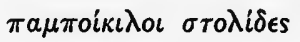

$$
\begin{aligned}
& \kappa \iota \sigma \sigma o \hat{v} \quad \tau \epsilon \quad \sigma \tau \epsilon \phi \theta \epsilon \hat{\imath} \sigma a \quad \chi \lambda \hat{o} a
\end{aligned}
$$

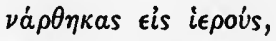

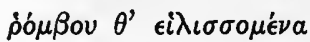

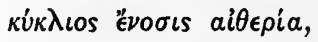

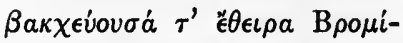

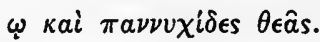

In Phoen. 226-228, there is a reference to the revels at Delphi; in 1751, to Bacchic revels on other mountains; in $649 \mathrm{ff}$., to the birth of Dionysus; and in 785, we are told that Ares is not at the feasts of Bromios.

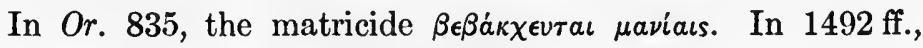
the young men seized Hermione

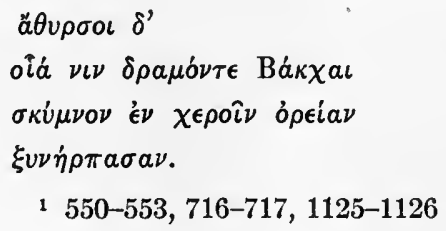




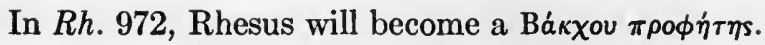

In Hypsipyle 1 ( $\left.\mathrm{N}^{2} .752\right)$, Dionysus is mentioned in connection with Delphi. In 41,106, Thoas is saved Baxxiov $\gamma \epsilon$ $\mu \eta \chi a \nu a i ̂ s$. Dionysus appears as deus ex machina. ${ }^{1}$

Some of the important fragments are:

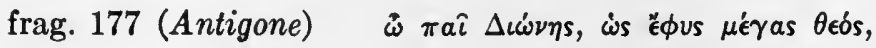

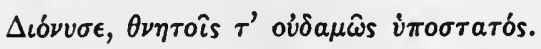

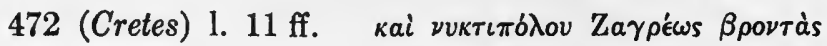

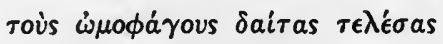

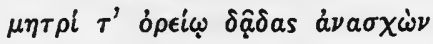

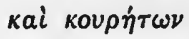

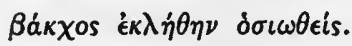

477 (Licymnius) where Dionysus and Apollo are identified.

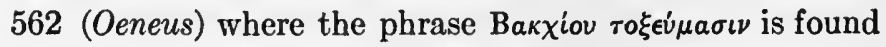
in a reference to the кórraßos.

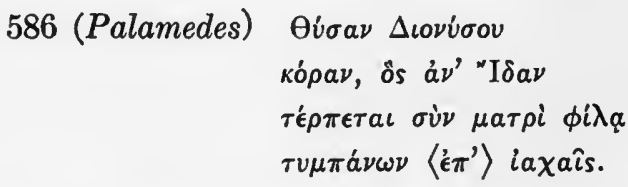

From these passages we can draw a few conclusions. Dionysus is the god of the Maenads and the midnight revel on the mountains. He is god of wine. He is often allied with the great Mother, Cybele, whose worship is also orgiastic. Frag. 472 is peculiarly valuable, as it shows conditions in Crete. ${ }^{2}$ The frenzy of a Cassandra and any madness take their names from him. Nowhere is there a condemnation of the god, except perhaps in frag. 177, and that is a tribute to his power.

Now we can consider the Bacchae. Dionysus, the son of Semele, comes to Thebes. The women are drawn by his power

${ }^{1}$ Cf. note on 41, 112 in Frag. Trag. Pap. and Petersen, Euripides' Hypsipyle, Rheinisches Museum, Vol. LXVIII, p. 584 ff.

2 Cf. Roscher, Lexikon, Vol. II, 1, pp. 1596. 
to Cithaeron. Pentheus resists the god and pays the penalty. As before, Dionysus is connected with the Mother. ${ }^{1}$ Tiresias defines the god's prophetic power:

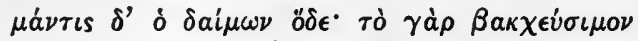

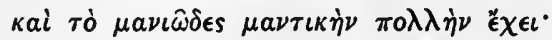

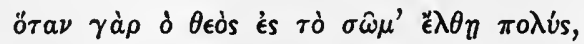

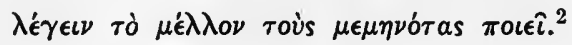

This explains the description of Cassandra in the Hecuba and

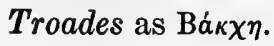

The offence of Pentheus is not only $v^{\prime} \beta \rho \iota s$ but also $\dot{a} \sigma^{\prime} \epsilon \in \epsilon \iota$, neglect of the new deity and therefore impiety. Dionysus says of him:

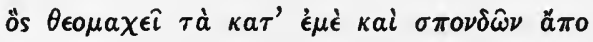

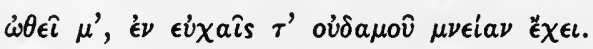

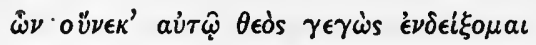

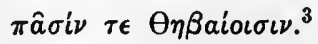

In 206-209, Tiresias states that the god wants honor from all, old and young. The á $\sigma^{\prime} \epsilon \epsilon \iota a$ of Pentheus is recognized by the messenger, ${ }^{4}$ Agave, ${ }^{5}$ and Cadmus. ${ }^{6}$ The king threatens to bring back the women by force $^{7}$ and has the god arrested.

1 Cf. 58-59,

and 72-82,

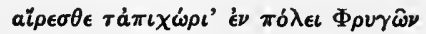

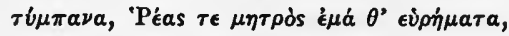

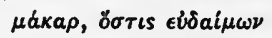

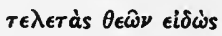

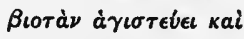

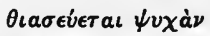

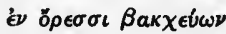

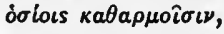

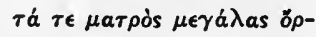

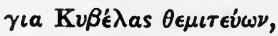

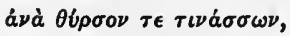

$\kappa \iota \sigma \sigma \hat{\varphi} \tau \epsilon \sigma \tau \epsilon \phi \alpha \nu \omega \theta \epsilon i s$

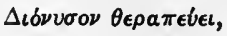

and 120-134.

2 298-301.

3 45-48.

4 1150-1152.

- 1303 .

s 1255-1256.

7 780-786. 
Yet in his blindness, he will not see that by escaping, Dionysus has shown superhuman power. Pentheus stands for respectability, for the maintenance of law, for the openness of action. The god praises darkness and secrecy.

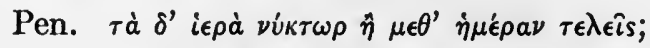

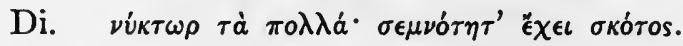

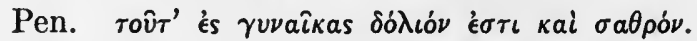

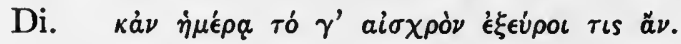

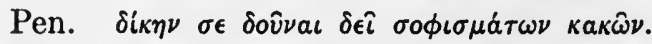

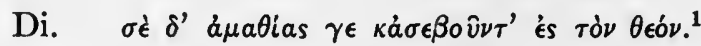

The appeal of Cadmus to Pentheus ${ }^{2}$ is not so open to condemnation as some think. The old man wants his grandson to prove true and be a god. Pentheus has absolutely refused to believe. Cadmus asks him to cease opposition on the ground of safety and cites the example of Actaeon, but the king will not yield.

Mr. Norwood ${ }^{3}$ and Prof. Verrall ${ }^{4}$ both deny that Euripides intended to represent Dionysus as a god. They think that he is drawn as a mortal of unusual daring and unscrupulousness, and they defend Pentheus. In their theories, the king is deceived by a bold impostor, if not actually drugged, and is then cruelly slain. These theories rest on the hypothesis that the prologue and deus ex machina are to be neglected in a correct interpretation of the play. As we have seen, ${ }^{5}$ such a method of treatment is without justification and destroys much of the beauty and practically all of the clarity of Euripides' art.

Pentheus is a ruler who is always ready to compel obedience to his laws by force - the dragon's seed. It is not by chance that he is again and again characterized as in $\mathbf{5 3 7} \mathrm{ff}$.:

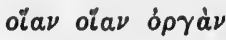

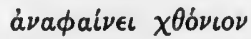
$1485-490$.
3 The Riddle of the Bacchae.
- Chap. I.
3 $330-342$.
The Bacchants of Euripides. 


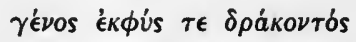

$$
\begin{aligned}
& \pi 0 \tau \epsilon \prod \epsilon \nu \theta \epsilon \dot{s}, \delta \hat{\nu} \nu ' \mathrm{E} \chi i \omega \nu
\end{aligned}
$$

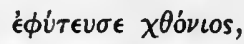

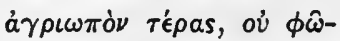

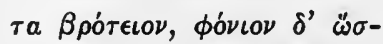

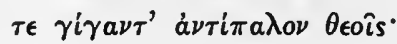

and 1015-1016:

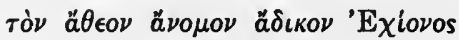

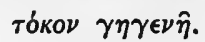

He mocks the idea that Zeus could beget new gods ${ }^{1}$ and wishes to destroy the property of Tiresias ${ }^{2}$ because he thinks the seer is pious only for the sake of gain. ${ }^{3}$ Such a character Euripides defends in no extant play.

In this play, Euripides has not changed his views of Dionysus. He knew from his own experience at Athens how despotism could lurk under the guise of freedom, and he knew the cruelty of those who fought to build an empire.

"In the Athens of Melos and the Sicilian expedition there was something that roused his aversion far more than did the mere ignorance of a stupid Greek farmer. It was a deeper 'amathia,' a more unteachable brutality. The men who spoke in the Melian Dialogue were full of what they called 'Sophia.' . . . And the Herd, as represented by Athens, followed them." 4

Pentheus is one of those leaders. The Dionysus of the poet was in a sense his own, but in the main, he is the Dionysus of tradition - of Thracian tradition, the real Dionysus of the people.

Did Euripides approve of this story? Prof. Macurdy ${ }^{5}$ regards the idea as shocking. Prof. Murray ${ }^{6}$ finds a shift of sympathy

1467.

346-351.

- The Chronology of the Extant Plays of Euripides, p. 127.

- Euripides and His Age, p. 185.

3 255-257.

- Murray, Euripides and His Age, p. $191 \mathrm{f}$. 
at the time when Dionysus becomes supreme just as in the $M e d e a$ and in other studies in revenge. We may think Dionysus cruel and unworthy of worship, but we must remember that many religious conceptions, to us commonplace and faded through familiarity, were unknown to the Greeks. The motto of Aeschylus was $\delta \rho \alpha \sigma a \nu \tau \iota \pi a \theta \epsilon i \nu$ - the soul that sinneth, it shall die - an idea founded on a solid basis of observed facts. Pentheus, impious and violent, matches himself against Di-

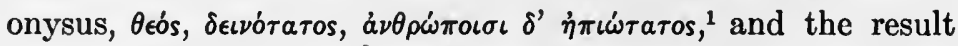
is never doubtful. The use made of Agave is cruel, but Pentheus was willing to use force against her ${ }^{2}$ and Aristophanes ${ }^{3}$ shows the enormity of such an offence.

Euripides always shows Dionysus as a powerful god and honors him throughout his whole career. He glorifies him in the Cyclops and still more in the Bacchae. This last mentioned play could be fairly judged only if we possessed a Dionysiac play of Aeschylus, for the spirit is almost that of the older poet and very different from that of Sophocles. We hear again the cry $\delta \rho a \dot{\sigma} \sigma \nu \tau \iota \pi a \theta \epsilon i \nu$. Although Euripides may have felt the cruelty of Dionysus, yet he obeys and worships him as a god who is on the whole beneficent and good, and he treats him as befits the especial deity of tragedy.

Note. - It is not without interest that the name Bromios ${ }^{4}$ does not occur in any known passage of Sophocles, whereas it is often found in the plays of Euripides, especially in the Cyclops and the Bacchae, the two dramas which most glorify Dionysus.

\section{A pollo}

In contrast to Dionysus, Apollo fares badly in the plays of Euripides, for he is one of the deities who are so treated as to give the impression that the poet was an atheist or a rationalist.

$1860 \mathrm{f}$.

$2229,780 \mathrm{ff}$.
- Nub. 1443 ff.

- Eum. 24. 
In the dramas of Aeschylus, Apollo is an exceedingly important god. He is primarily the prophet, as he himself acknowledges in Eum. 614-621:

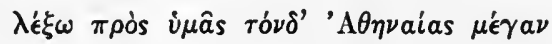

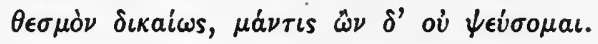

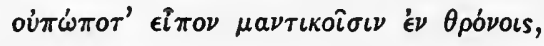

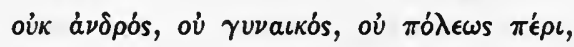

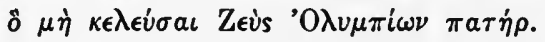

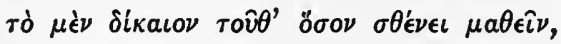

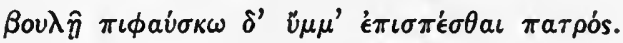

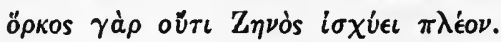

Yet the poet does not hide faults or seeming faults in the god's history and character. In Eum. 727-728, the Furies say:

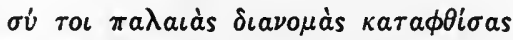

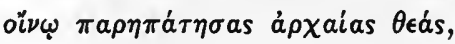

a charge which has no effect upon the god. Similarly in frag. 350 , Thetis accuses him of murdering Achilles. The general impression is that Apollo is a god of light, who may at times seem unjust but who is finally justified. The Eumenides shows the superiority of his rule to that of the older gods, the children of eternal Night. ${ }^{1}$

As we should expect, Aeschylus is very careful in his choice of epithets. The name Loxias, commonly applied to the god in his prophetic character, but not a cult-title, ${ }^{2}$ is commonly used in passages referring to prophecy, as $C h .900^{3}$ and Eum. 19. In a few cases, as $C h .952$, there appears to be less reason for choosing this epithet. Aeschylus is rather fond

1416 , Nukròs alavîs rékva.

2 Farnell, The Cults of the Greek States, Vol. IV, p. 219, note a.

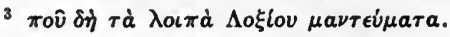

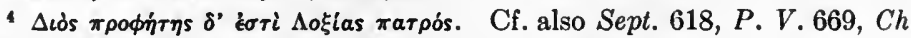
269, 558, 1030, 1036, 1039, Eum. 61, 235, 241, 465. 
of the vocative of $A$ pollo ${ }^{1}$ but otherwise he uses the epithet in various relations. Phoebus rarely occurs. It is distinctly connected with the prophetic character of the god only in Eum. 8 and frag. 350, 11. 5-6. We find it elsewhere in Pers. 206, Sept. 691, Eum. 283, 744. Aeschylus then clearly prefers both A pollo and Loxias to Phoebus.

To Sophocles, who frequently mentions Apollo, the god is the lord of Delphi and is often invoked. The poet's

"aim is not to use the story as the basis of a religious poem, but to present the story itself: he accepts its morality, and uses its religious ideas." 2

Because of this attitude, Sophocles gives few passages that are worth quoting. The most significant is $O . R$. $708 \mathrm{ff}$. To console Oedipus, Jocasta says:

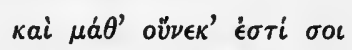

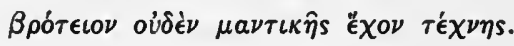

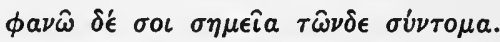

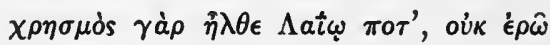

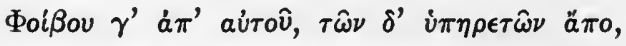

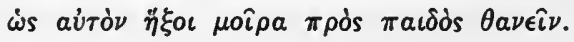

The chorus sings:

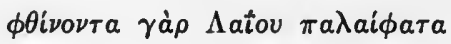

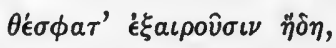

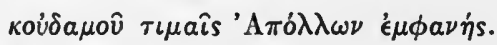

$$
\begin{aligned}
& \text { ๕e } \rho \rho \epsilon \iota \dot{\epsilon} \tau \dot{a} \theta \epsilon \hat{\imath} a .^{3}
\end{aligned}
$$

But the oracles come true. Sophocles holds the conventional

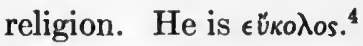

Sophocles prefers the cpithet Phoebus and uses it freely in all connections, including that of prophecy. ${ }^{5}$ He employs

${ }_{1}$ Cf. Sept. 159, Ag. 1073, 1077, 1080, 1085, 1257, Ch. 1057, Eum. 85, 198, 574, 610, 744 .

2 Sheppard, Greek Tragedy, p. 89. 'Aristoph., Ran. 82.

3906 ff.

' Cf. O. R. 149, 305, 712, 1011. 
Apollo frequently but not so often in the vocative as does Aeschylus. Loxias is rare. It occurs three times in the prophetic sense ${ }^{1}$ and the same number of times without special significance. $^{2}$

In regard to epithets, Euripides does not follow strictly the usage of Aeschylus, because of his fondness for Phoebus, which he uses most frequently of all the titles. Yet he employs Loxias more freely than Sophocles does. In 28 cases, ${ }^{3}$ it occurs in the strict sense. In 5 other cases, ${ }^{4}$ the passage refers to Delphi. In $16,{ }^{5}$ there seems little reason for the selection. Apollo does not occur in the vocative as freely as in the plays of Aeschylus. Euripides agrees with Aeschylus in using this epithet frequently in scenes in which Cassandra has a part. So in Ag. 1072-1330, Apollo occurs 11 times and Loxias 3. Perhaps this choice is

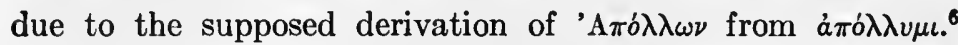
So in Tro. 308-461, Apollo occurs three times, Loxias and Phoebus each once. Loxias ${ }^{7}$ is probably chosen because of the special emphasis laid on the prophetic honor of the god.

Despite this verbal archaism, Euripides conceives of Apollo in a way very different from that of his predecessors. To him Phoebus is neither a benign nor a conventional deity. $\mathrm{He}$ is everything that a man, much less a god, should not be. Let us now look at some of the poet's judgments about him.

I O. R. $853,994, \mathrm{El} .82$.

O. R. 1103, Ichneutae, 367, 436.

Her. 1028, Supp. 7, Ion 67, 72, 243, 531, 728, 774, 781, 974, 1347, Tro. 356, El. 399, 1266, I. T. 943, 1013, 1084, 1280, 1438, Phoen. 284, 409, 1703, Or. 165, 285, 1666, 1681, Bacch. 1336, Melanippe, 14 (Frag. Trag. Pap.).

- And. 51, 1065, Ion 187, 1455, Phoen. 215.

- Ion $36,78,311,425,931,1218,1287,1531,1540,1548,1608$, Tro. 1174, Or. 268, 419, Rh. 979, frag. 455 (Cresphontes).

Cf. 1080-1082.

$$
\begin{aligned}
& \text { "A } \pi 0 \lambda \lambda O \nu " A \pi 0 \lambda \lambda o \nu
\end{aligned}
$$

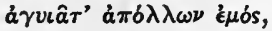

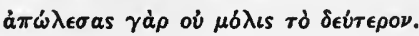

756. 
In Alc. $28 \mathrm{ff}$., Thanatos attacks him for saving Admetus and deceiving the Fates as the Erinyes do in the Eumenides. When the god tries to save Alcestis by saying that Thanatos would receive rich gifts if the queen should die in old age, he receives the answer:

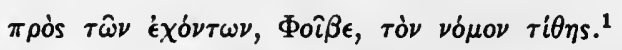

Probably, however, Euripides did not intend this scene to be taken seriously.

The Andromache contains the next case of hostility. Neoptolemus went to Delphi to ask Phoebus to atone for the death of Achilles. While on a second trip to obtain pardon for the sin which he has thus committed, ${ }^{2}$ he is slain by the machinations of Orestes. Old Peleus, in accusing the god of murder, says:

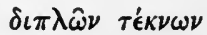

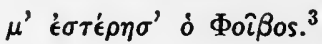

Thetis orders the burial of Neoptolemus at Delphi as $\Delta \epsilon \lambda \phi$ îs

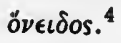

The poet soon advances beyond this stage. In the Ion, a thinly veiled attack on the god, everything ends happily, but the play shows the shortsightedness of the god. He practically sends word by Athena that he does not dare to meet his former bride:

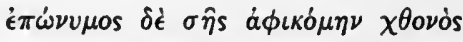

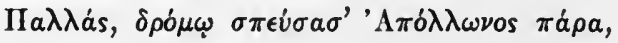

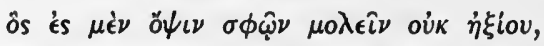

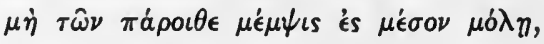

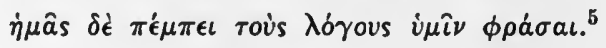

She then says that Apollo intended to reveal Ion's parentage at Athens. There is no excuse made for the god's cruelty in abandoning Creusa. True are the words of Ion:
157.
${ }^{3} 1212-1213$.
- $1555 \mathrm{ff}$.
$349-55$.
1241. 


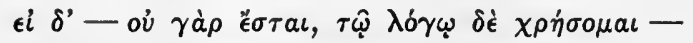

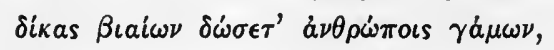

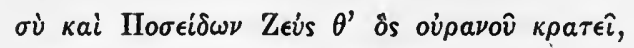

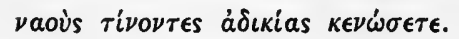

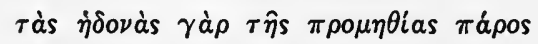

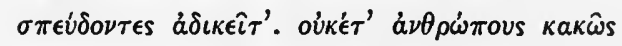

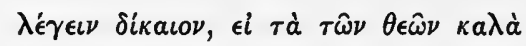

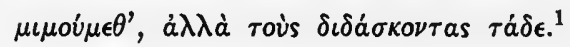

In the Electra, Euripides continues the attack. The matricides condemn Apollo:

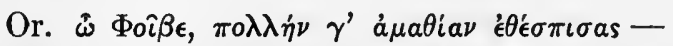

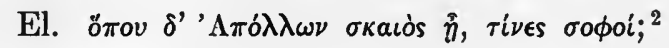

The Dioscuri blame him:

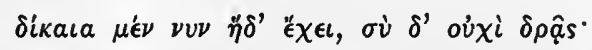

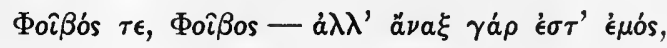

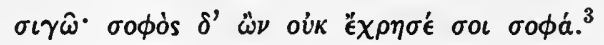

They did not save Clytaemestra because

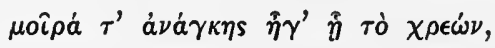

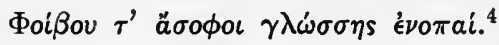

In the Iphigenia in Tauris, Orestes several times reproaches Apollo, as in 711:

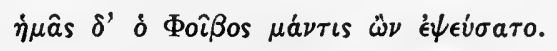

However, the oracles are fulfilled and so it is shown that Apollo is not the rogue that he at first seemed to be. Then, too, the ode 1234-1283 does not put Apollo's acquisition of Delphi in a very creditable light.

The Orestes contains more attacks on the god's honesty and veracity. Among such instances are:
$1444 \mathrm{ff}$.
${ }^{3}$ 1244-1246.
$2971-972$.
4 1301-1302. 
and

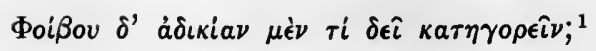

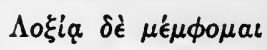

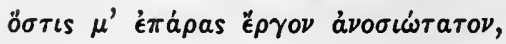

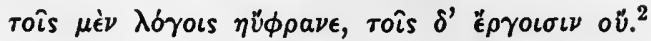

Here again the oracles are fulfilled and so Orestes says:

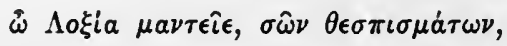

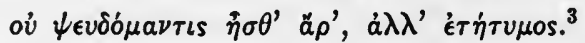

These are among the most significant comments on Apollo. We notice at once how they differ in tone from those which relate to Dionysus. There was respect; here, contempt; there, worship; here, revolt. What did Euripides think of Apollo?

Evidently he did not admire the god of the silver bow. $\mathrm{He}$ never loses a chance to attack him, and we have seen how he clearly removes dreams from the sphere of Apollo's influence and restores them to $\mathrm{X} \theta \dot{\omega} \nu .{ }^{4} \quad \mathrm{He}$ so consistently represents Phoebus as foolish, unwise, even criminal, that he seems to bear the god special hatred.

Are we to agree with Prof. Verrall ${ }^{5}$ that Euripides never believed in him as a real being? It seems unnecessary to hold that the poet intended the intelligent hearer to disregard prologue and epilogue and then to rearrange the story of the intervening part. If we deny the personal reality of Apollo, our interpretation of the plays is often forced.

How are we to regard Delphi? As a gigantic fraud arranged to deceive well-meaning people? Yet on the whole it is clear that the god, himself, is responsible. A Jocasta may throw blame on the servants of Apollo. Euripides, as an honest enemy, realizes that his real enemy is the god, not the prophet. The unimportance of the priests is surprising. We hear a great deal about oracles, but we can hardly regard them as the work
128.
$2285-287$.
- Chap. VIII.
3 1666-1667
- Euripides the Rationalist, p. 146. 
of the priests as distinct from the god. This attack on Apollo as the responsible person is to be contrasted with the poet's attitude in the Iphigenia in Aulide, one of his latest plays. There we hear very little of Apollo but much of Calchas. So the old man, in response to Clytaemestra's question as to the reason for the sacrifice of Iphigenia, says:

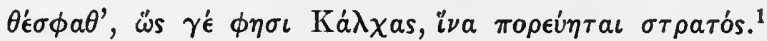

Throughout, one wonders how much responsibility is to be laid upon Calchas and how much upon the deity. Euripides, adopting an attitude toward Apollo unusual for him, has tried to suggest that Calchas is responsible for the crime. ${ }^{2}$ Except in this play, the god is throughout the cause of religious wrong.

If it is incorrect to regard Apollo as simply non-existent and to interpret the plays as attacks on Delphi, what shall we say? It is true that in many cases we have an apparent orthodoxy at the end. Yet the Ion seems to be the work of an unbeliever, and must be regarded as an attack on the god. No one who thought at all, could find anything but condemnation for a being who would abandon his child and its mother so cheerfully. Similarly in the Electra, every one would agree with the statement of the Dioscuri about the folly of the god. But who would consult a god, if one knew that he might give the most unsuitable advice?

Euripides'

"tendency was to treat the story as a piece of ordinary life, though he was checked at every turn by convention. The result is inevitably that the legend, thus presented, is exposed. Euripides was aware of that, and was sometimes quite deliberately exposing latent immorality. Sometimes he meant his audience to feel uneasy, to think that if the story were true it was highly discreditable: sometimes he meant them to infer that it was not true." ${ }^{3}$

$1879 . \quad 2$ Cf. Masqueray, Euripide et ses idées, p. 152.

3 Sheppard, Greek Tragedy, p. 137 f. 
That is what is involved in the rebukes of Apollo. Euripides does not deny the god's existence; he merely exposes the myth.

In this, the poet could not be prosecuted for impiety. Apollo always rises to the occasion and does what he should. His oracles come true. At most, the spectators might suspect; they could prove nothing about the personal faith of the poet.

It is interesting, however, to find that Apollo aroused Euripides' ire. The god, whom Aeschylus treated as a beneficent deity, is changed. Perhaps his worship was too well-defined, too open for the later poet. In Eum. 416, the Erinyes opposed

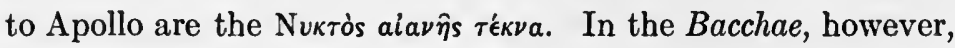
Dionysus says:

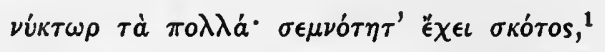

and

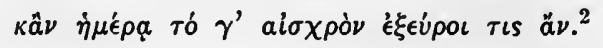

Both Dionysus and Apollo were worshipped at Delphi, but the two became friends probably only after a long contest, for they were of different origins. ${ }^{3}$ Euripides did not try to respect both. He followed Dionysus the mystic.

It is clear that the poet did not trust Apollo. Perhaps since the priests at Delphi favored the Spartans, ${ }^{1}$ Euripides was too patriotic to honor a god who was partial to his country's enemies. Since he was writing for a religious festival, he could not deny the god's existence, even if he did not believe. Consequently he depicts him in such a way that the most unintellectual of the audience would feel such a god unfit for honor, much less for worship, - a method of attack far more effective and insidious than an open denial would have been. Whatever the poet's belief, he assumes the existence of Apollo in his plays, for he aimed to present the god as a contemptible character and to allow the audience to draw its own conclusions. Dionysus he praises, Apollo he condemns. In so doing, Euripides
1486.
2488.
3 Cf. Rohde, Psyche 5 , II, p. 52.
- Wilamowitz, Apollo, p. 39. 
practically revives the old idea of a struggle between the gods, and moves tragedy back toward its original position by discrediting Zeus and Apollo, and elevating Dionysus, the original patron of tragedy.

\section{Athena}

As the especial deity of Athens, the virgin goddess Pallas Athena occupies a somewhat unusual position in Greek tragedy. Because of her relationship to the state, it was probably expedient that she be treated with particular respect. Indeed she stands as a representative of certain tendencies which Athens idealized, and even, in a way, of the city itself, as in Supp. 711-712, where Euripides has Theseus quoted as saying:

$$
\begin{aligned}
& \bar{\omega} \pi a \hat{\imath} \delta \epsilon s, \epsilon \hat{i} \mu \grave{\eta} \sigma \chi \dot{\eta} \sigma \epsilon \tau \epsilon \sigma \tau \epsilon \rho \rho \dot{\nu} \boldsymbol{\delta} \delta \dot{\rho} v
\end{aligned}
$$

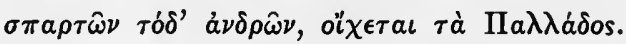

In the Eumenides of Aeschylus, Athena plays an important part. It is her action in conjunction with the Court of the Areopagus, which she establishes, that frees Orestes from the pursuit of the Erinyes and so vindicates Apollo. This means the god of the silver bow has chosen to give human and divine sanction to his oracle. He says to the Erinyes:

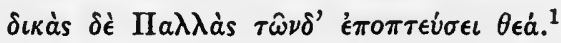

By her act the goddess renders Argos friendly to Athens. ${ }^{2}$ The goddess is also mentioned in Pers. 347, where Athens is called

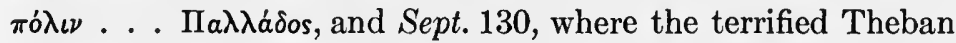
maidens appeal to the goddess. In the extant plays, her usual

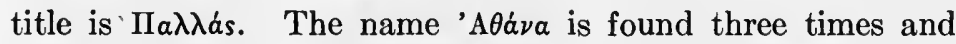
always in the vocative. ${ }^{3}$ The longer form 'A $\theta$ pvaia occurs three times. ${ }^{4}$

Athena appears once in the extant plays of Sophocles, in the Ajax. Here her rôle is quite different. She is the stern and jealous goddess, the punisher of Ajax. Tecmessa says of her:

\footnotetext{
1224.

$2754 \mathrm{ff}$.

${ }^{3}$ Eum. 235, 443, 892.

4 Eum. 288, 299, 614.
} 


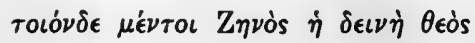

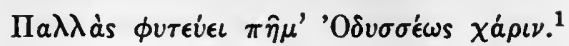

Sophocles prefers the name Athena, which occurs ten times. ${ }^{2}$ Pallas occurs five times ${ }^{3}$ and Pallas Athena ${ }^{4}$ once. Only in O. C. 107:

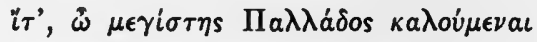

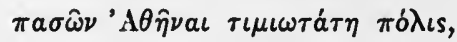

is this epithet used in connection with Athens. It is mentioned three times in reference to Thebes. In Phil. 134, the goddess

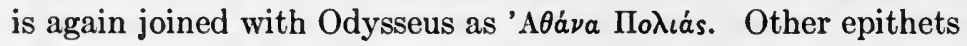
occur in O.C. 706, 1071.

Athena appears in the drama of Euripides more frequently than any other deity. In three, Supplices, Ion, Iphigenia in Tauris, she comes as a deus ex machina at the end of the play. Her appearance then is in a way parallel to that in the $E u$ menides. In the Iphigenia in Tauris, she prevents Thoas from pursuing Orestes and so again causes the fulfilment of the oracle of Apollo. In 966, we have an allusion to her intervention at the trial in Athens. In the Ion, she comes again to clear away the difficulties which the oracle of Apollo has caused and which the god is himself unable or unwilling to remove. Both of these interventions bring help and power to Athens, the former giving it possession of the statue of Artemis, the latter restoring to it the heir of Erechtheus and the ancestor of the Ionians. In the third case, the Supplices, she is introduced not to help Apollo but merely to strengthen Athens. She gives directions to Theseus concerning the agreement which he is to make with Adrastus so that Athens and Argos may be friendly. Incidentally she orders Theseus to have the oath preserved at Delphi under the guardianship of Apollo.

1 952-953.

2 Aj. 14, 74, 91, 112, 757, 771, O. R. 159, Phil. 134, O. C. 706, 1071.

Ant. 1184, Aj, 953, Tr, 1031, O. R. 20, O. C. 107.

' O. C. 1090 . 
In the above cases, the rôle of Athena is similar to that which she had in the Eumenides. In the two other plays in which she appears, she plays a part somewhat analogous to that which she had in the Ajax. So in the Troades, she is the angry goddess slighted by the outrage of Ajax against Cassandra, and she plans to punish the Greeks who have failed to protest,

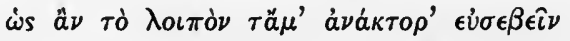

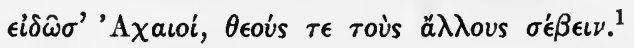

To be sure this might be construed as pettiness on the part of the divinity, and there is some irony in the treatment of the goddess whose favorites have insulted her, but on the whole she is presented with perhaps more reverence than in the $A j a x$, where she summons the unhappy man to show him in his degradation to Odysseus.

In the Rhesus, Athena as the friend of Odysseus directs him to the camp of Rhesus and deceives Paris who is coming to Hector to tell him about the intruders. ${ }^{2}$ This illustrates Phil. 134 or Rh. 609-610, where Odysseus says to the goddess:

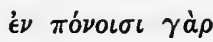

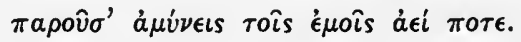

In $938 \mathrm{ff}$., the Muse rebukes her for the death of Rhesus, but this is more of an attack on war than on the goddess herself. In fact both the Troades and the Rhesus show the horrible and inhuman character of war.

In some passages, the goddess is connected with the fortunes of Heracles and his family. So in $T r$. 1031, the suffering Heracles invokes her. In $H . F$., she saves Amphitryon and stops the mad career of Heracles by stunning him until the fit of madness has passed away. ${ }^{3}$

Athens is particularly the favorite of the goddess. Besides numerous allusions to the city as the possession of the goddess, ${ }^{4}$
$185-86$.
3 Cf. $907,1003 \mathrm{f}$.
$2595 \mathrm{ff}$.
I. T. 1014, etc. 
there are passages where this usage is extended, as in Supp. 711-712. So she is regarded as the divine helper of the Athenian army in Her. 349-350,

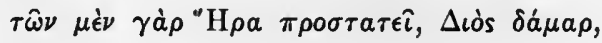

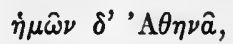

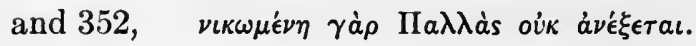

Euripides mentions the goddess in connection with various other stories, as that of the contest of the three goddesses before Paris, ${ }^{1}$ and with her temple in Thebes. ${ }^{2}$

As regards the choice of epithet, Euripides follows the usage of Aeschylus and prefers the title Pallas. There seems to be in many passages little reason for the choice, save that the latter title is the more common where the goddess is connected with Athens.

Athena, as we might expect, is handled kindly by Euripides. Aeschylus shows her in the Eumenides as confirming the oracles of Apollo, and Euripides does the same in several plays. Even where this is not her purpose, she usually intervenes in the interest of some one, whether it be Athens, Odysseus, or Heracles. It is only in the Troades that we see her angered and destructive, more as in the Ajax.

Euripides treats Athena as a beneficent goddess and in rôles similar to that in Aeschylus' works, although she appears in others, owing to the greater number of stories treated in the extant plays. Yet these appearanees do not bear so purely a religious character as do the referenees to Dionysus. Athena is a goddess, and as the patroness of Athens, she is treated with respect. Still throughout she bears a little too much of the character of the deus ex machina for us to judge how truly Euripides believed in her, although he represented her in the orthodox way.

1Tro. 925, $971 \mathrm{ff} ., I . A .183,1300 \mathrm{ff}$.

2 Phoen. 1062, 1372. 



\section{LIST OF THE PRINCIPAL WORKS CITED}

\section{EDITIONS}

Aeschyli Tragoediae. A. Sidgwick. Oxford Text.

Sophocles. The Text of the Seven Plays. R. C. Jebb. Cambridge, 1897. Euripides Fabulae. G. Murray. Oxford Text.

Tragicorum Graecorum Fragmenta. A. Nauck. ${ }^{2}$ Leipzig, 1889.

Fragmenta Tragica Papyracea. A. S. Hunt. Oxford Text.

Aristophanis Comoediae. F. W. Hall and W. M. Geldart. Oxford Text. The Supplices of Aeschylus. T. G. Tucker. London, 1889.

The Agamemnon of Aeschylus. A. W. Verrall. London, 1904.

Aeschylus' Eumenides. A. Sidgwick. ${ }^{3}$ Oxford, 1902.

Aeschylos' Orestie. N. Wecklein. Leipzig, 1888.

Aeschylus' Septem contra Thebas. A. Sidgwick. Oxford, 1903.

Prometheus Bound of Aeschylus. N. Wecklein and F. D. Allen.

Sophocles' Ajax. R. C. Jebb. Cambridge, 1907.

Boston, 1891.

Sophocles' Philoctetes. R. C. Jebb. Cambridge, 1890.

Sept Tragédies d' Euripide. H. Weil ${ }^{3}$. Paris, 1905.

Euripides' Hecuba. C. B. Heberden. Oxford, 1901.

Aristotle on the Art of Poetry. I. Bywater. Oxford, 1909.

\section{OTHER WORKS}

Croiset, M. De la tétralogie dans la tragédie grecque. Revue des études grecques, Vol. I.

Decharme, P. Euripide et l'esprit de son théâtre. Paris, 1893.

Detscheff, D. De tragoediarum Graccarum conformatione scaenica ac dramatica. Göttingen, 1904.

Dren, L. The Plot of the Agamemnon. Harvard Studies, Vol. VII.

Farnell, L. R. The Cults of the Greek States. Oxford, 1896-1909.

Freericks, H. De Aeschyli Supplicum choro. Duderstadt, 1883.

Fries, H. De conexu chori personae cum fabulae actione. Göttingen, 1913.

Girard, P. La trilogie chez Euripide. Revue des études grecques, Vol. XVII.

Henning, E. De tragicorum Atticorum narrationibus. Göttingen, 1910.

KANZ, J. De tetrametro trochaico. Darmstadt, 1913.

Krausse, O. De Euripide Aeschyli instauratore. Jena, 1905. 
MAcurdy, G. H. The Chronology of the Extant Plays of Euripides. Lancaster, 1905.

Masqueray, P. Euripide et ses idées. Paris, 1908.

Murray, G. History of Ancient Greek Literature. London, 1908.

Ritual Forms in Greek Tragedy. (J. E. Harrison; Themis.) Cambridge, 1912.

Euripides and His Age. London, 1913.

Petersen, E. Euripides' Hypsipyle. Rheinisches Museum, Vol. LXVIII. Platt, A. The Burial of Ajax. Classical Review, Vol. XXV.

Post, C. R. The Dramatic Art of Aeschylus. Harvard Studies, Vol. XVI. RонDE, E. Psyche. ${ }^{5}$ Tübingen, 1910.

Roscher, W. H. Ausführliches Lexikon der griechischen und römischen Mythologie. Leipzig, 1884-1915.

Scort, W. The "Mountain-Mother" Ode in the Helena of Euripides. Classical Quarterly, Vol. III.

Sheppard, J. T. The First Scene of the Suppliants of Aeschylus. Classical Quarterly, Vol. V.

Greek Tragedy. Cambridge, 1911.

Sмyтн, H. W. The Anapaests of Aischylos. Harvard Studies, Vol. VII. Verrall, A. W. Euripides the Rationalist. Cambridge, 1895.

Essays on Four Plays of Euripides. Cambridge, 1905.

The Bacchants of Euripides. Cambridge, 1909.

Welcker, F. G. Die Aeschylische Trilogie Prometheus. Darmstadt, 1824.

Wilamowitz-Moellendorff, U. von. Analecta Euripidea. Berlin,1876.

Die Perser des Aischylos. Hermes, Vol. XXXII.

Drei Schlußscenen. Sitzungsbericht d. kgl. Preuß. Akad. zu Berlin, Phil.-Hist. Klasse, 1903.

Apollo. Oxford, 1908. 


\section{COLUMBIA UNIVERSITY PRESS}

Columbia University in the City of New York

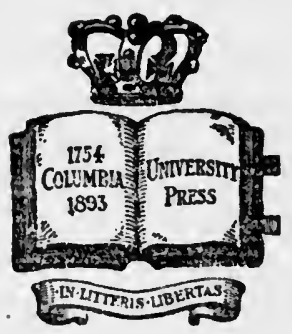

The Press was incorporated June 8, 1893, to promote the publication of the results of original research. It is a private corporation, related directly to Columbia University by the provisions that its Trustees shall be officers of the University and that the President of Columbia University shall be President of the Press.

The publications of the Columbia University Press include works on Biography, History, Economics, Education, Philosophy, Linguistics, and Literature, and the following series:

Columbia University Contributions to Anthropology.

Columbia University Biological Series.

Columbia University Studies in Cancer and Allied Subjects.

Columbia University Studies in Classical Philology.

Columbia University Studies in Comparative Literature.

Columbia University Studies in English.

Columbia University Geological Series.

Columbia University Germanic Studies.

Columbia University Indo-Iranian Series.

Columbia University Contributions to Oriental History and Philology.

Columbia University Oriental Studies.

Columbia University Studies in Romance Philology and Literature.

Records of Civilization: Sources and Studies.

Adams Lectures. Julius Beer Lectures.

Blumenthal Lectures.

Carpentier Lectures.

Hewitt Lectures.

Jesup Lectures.

Catalogues will be sent free on application.

\section{LEMCKE \& BUECHNER, Agents} 30-32 West 27th ST., NEW YORK 


\section{COLUMBIA UNIVERSITY PRESS}

\section{COLUMBIA UNIVERSITY STUDIES IN CLASSICAL PHILOLOGY}

Edited by the Department of Classical Philology

THE SATIRE OF SENECA ON THE APOTHEOSIS OF CLAUDIUS, COMMONLY CALLED THE AIIOKO $\Lambda 0-$ Krntrziz. A Study. By Allan Perley Ball, Ph.D. $12 \mathrm{mo}$, cloth, pp. vii +256 . Price, $\$ 1.25$ net. STRESS ACCENT IN LATIN POETRY. By ELIZABETH Hickman DU BoIs, Ph.D. 12mo, cloth, pp. v +96 . Price, $\$ 1.25$ net.

STUDIES IN THE PHILOSOPHICAL TERMINOLOGY OF LUCRETIUS AND CICERO. By Katharine C. Reiley, Ph.D. 12mo, cloth, pp. ix +133 . Price, $\$ 1.25$ net.

COSTUME IN ROMAN COMEDY. By CathaRINe Saunders, Ph.D. $12 \mathrm{mo}$, cloth, pp. $\mathrm{x}+145$. Price, $\$ 1.25$ net.

DE INFINITIVI FINALIS VEL CONSECUTIVI CONSTRUCTIONE APUD PRISCOS POETAS GRAECOS. By Charles Jones Ogden, Ph.D. 8vo, cloth, pp. 65 . Price, $\$ 1.00$ net.

THE BELLUM CIVILE OF PETRONIUS. By FLORENCE T. Baldwin, Ph.D. 12mo, cloth, pp. viii +264 . Price, $\$ 1.25$ net.

RELIGIOUS CULTS ASSOCIATED WITH THE AMAZONS. By Florence Mary Bennett, Ph.D. 8vo, pp. ix +79. Price, cloth, $\$ 1.25$ net, paper $\$ 1.00$ net.

A STUDY OF ARCHAISM IN EURIPIDES. By ClARence Augustus Manning, Ph.D. 8vo, cloth, pp. xi + 98. Price, $\$ 1.25$ net.

STUDIES FROM MAGIC IN LATIN LITERATURE. By Eugene Tavenner, Ph.D. 8vo, cloth. In press.

LEMCKE \& BUECHNER, Agents 30-32 West 27th Street NEW YORK 




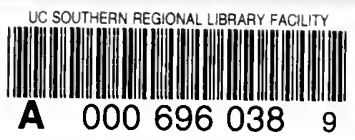


